

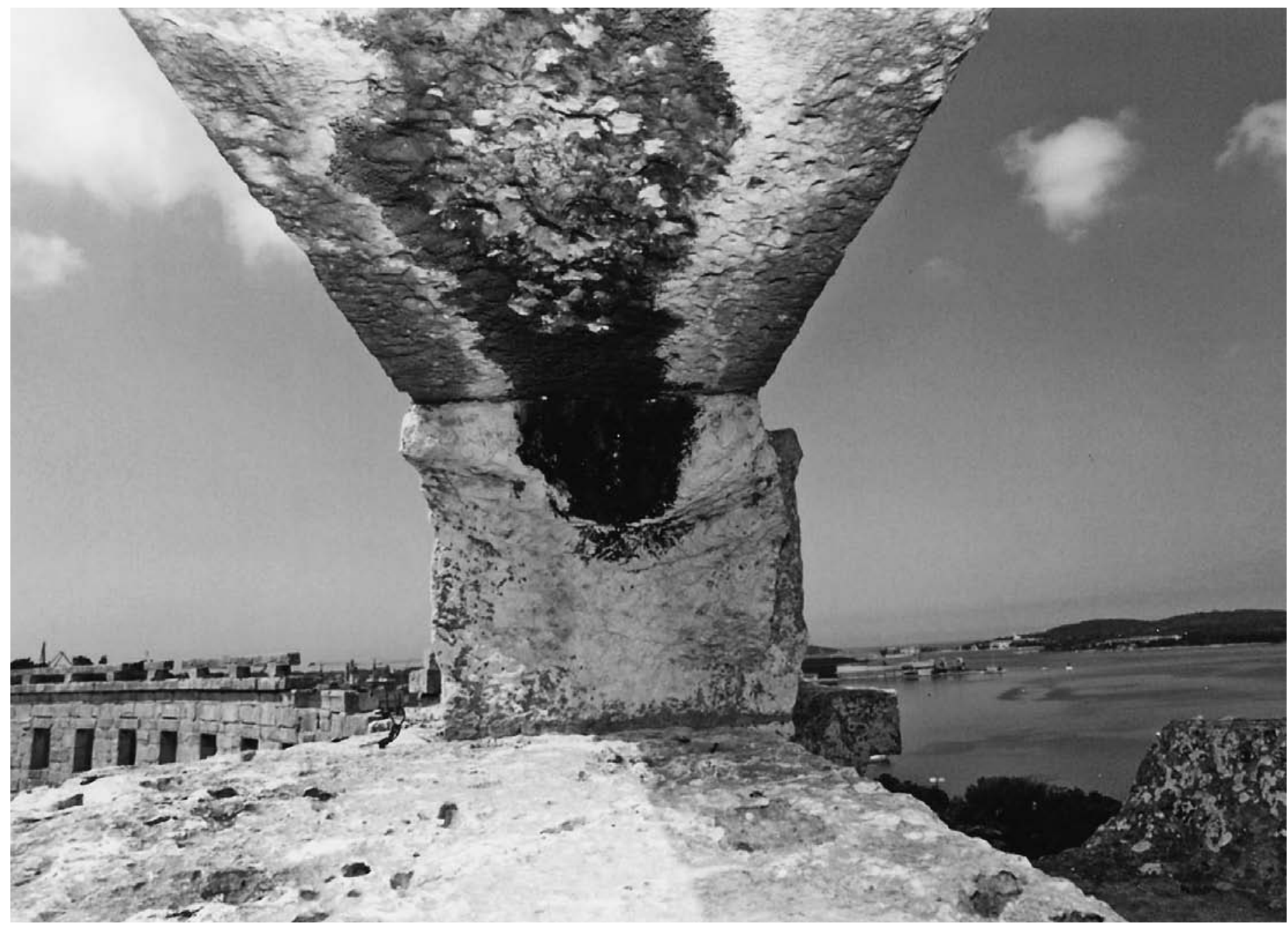

SL. 1. BITVA NA POZ. 32 NA KOJOJ JE BIO PRIVEZAN JEDAN DONJI NOSIVI ZATEZNI ŚTRAJ VELARIJA

FIG. 1 BOLLARD ON THE POS. 32 WHERE A LOWER TENSIONING BACKSTAY OF THE VELARIUM IS TIED 


\title{
Attilio Krizmanić
}

HR - 52100 PULA, TOMASINIJEVA 33

krizmatti@gmail.com

IZVORNI ZNANSTVENI ČLANAK

https://doi.org/10.31522/p.28.2(60).1

UDK 72.032:725.826 (497.5 PULA) "1/20"

TEHNIČKE ZNANOSTI / ARHITEKTURA I URBANIZAM

2.01.04. - POVIJEST I TEORIJA ARHITEKTURE

I ZAŠTITA GRADITELJSKOG NASLIJEDA

ČLANAK PRIMLJEN / PRIHVACEN: 23. 10. 2020. / 16. 12. 2020.
HR - 52100 PULA, TOMASINIJEVA 33

krizmatti@gmail.com

ORIGINAL SCIENTIFIC PAPER

https://doi.org/10.31522/p.28.2(60).1

UDC 72.032:725.826 (497.5 PULA) "1/20"

TeChNical SCIEnCES / ARChitecture ANd URban Planning

2.01.04. - HISTORY AND THEORY OF ARCHITECTURE and Preservation of the Built Heritage

Article Received / AcCepted: 23. 10. 2020. / 16. 12. 2020

\section{AMFITEATAR U PULI \\ VELARIJ}

\section{AMPHITHEATRE IN PULA}

\author{
VELARIUM
}

\author{
AMFITEATAR \\ ANTIKA \\ IZVORNO STANJE \\ PULA \\ VELARIJ
}

O velariju i njegovu sustavu pisao sam 2016. godine. Tada sam tvrdio da su na pulskom Amfiteatru, na njegovoj četvrtoj etażi, očuvani jedinstveni detalji u kamenu koji omogucuju proučavanje konstrukcije rimskoga velarija kao ni na jednome drugom amfiteatru na svijetu. U sklopu velarija tada se konačno riješila konstrukcija zagonetne summae cavee in ligneis s pripadajucim palubama na četvrtoj etażi. Naglašen je najprije velarij jer je njegova osobita konstrukcija svojevrsna zaključnica Amfiteatra, koja ne završava samim isticanjem 84 drvena jarbola, i to u pravilu bez zatege (štraja), umjesto $s$ isprepletenim konopima velarija duž kojih se sekcija razvlače i namještaju jedra u odnosu na momentalni polożaj Sunca ili na smjer, intenzitet i učestalost kiše nošene vjetrom, ili pak smirena bonacom. Glavnih je nosača velarija ukupno bilo 84 jarbola (68: $30 \times 30 \mathrm{~cm}$ i 16: $18 \times 20 \mathrm{~cm}$ ), a ne 72 kako se redovito navodi.

\author{
AMPHITHEATRE \\ ANTIQUITY \\ ORIGINAL CONDITION \\ PULA \\ VELARIUM
}

I wrote about the velarium system in 2016. I asserted then that, unlike any other amphitheatre in the world, the Amphitheatre in Pula (specifically its fourth level) boasts unique preserved stone details that provide insight into the construction of the Roman velaria. In this context the puzzling construction of summa cavea in ligneis with the associated decks on the fourth floor was finally solved. The emphasis is put on the velarium first due to its unique construction which completes the Amphitheatre. It consists not only of 84 wooden masts without backstays but also of the intertwined velaria ropes which serve to stretch and adjust the sails in relation to the current position of the sun or the direction, intensity and frequency of the prevailing winds and rainfall. There was a total of 84 masts as the main velarium carriers $(68: 30 \times 30 \mathrm{~cm}$ and 16: $18 \times 20 \mathrm{~cm}$ ), not 72 as often stated. 


\section{UVOD: \\ STVARANJE I RUKOVANJE VELARIJEM}

\author{
INTRODUCTION: \\ DESIGNING AND OPERATING \\ THE VELARIUM
}

SL. 2. RIMSKI GRAD POLA, 2. ST. N. E.

FIG. 2 PULA, A ROMAN CITY, $2^{\text {ND }}$ CENTURY AD

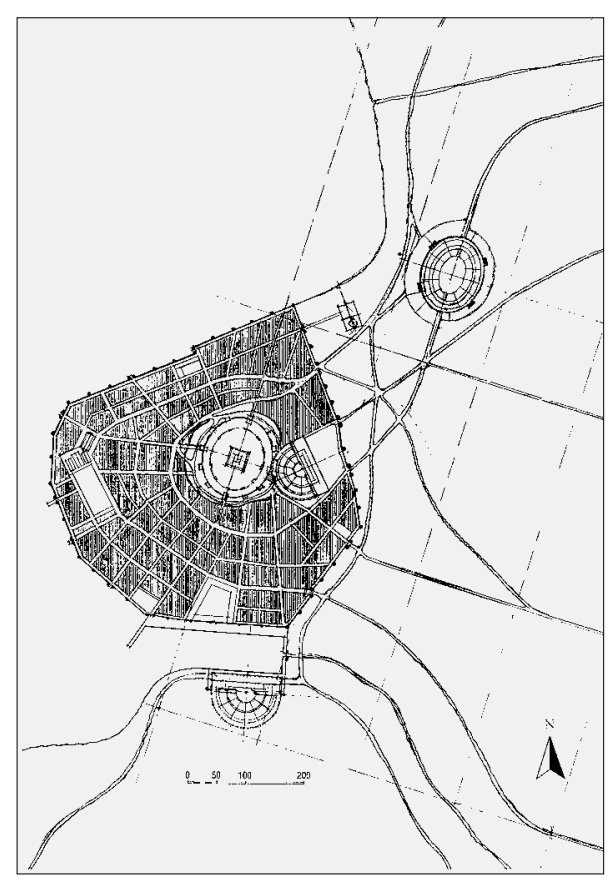

ovoriti o izvornome stanju Amfiteatra u Puli, a detaljno ne obrazložiti sustav i kako se rukovalo velarijem ${ }^{1}$, ostao bi neriješen bitni dio Amfiteatra koji ga određuje kao osobitu rimsku građevinu. ${ }^{2} U$ novije se vrijeme često tvrdi da se obrazovanje arhitekta projektanta Koloseuma u Rimu treba smjestiti u brodograđevnu tehnologiju. ${ }^{3}$ Kao što je vidljivo iz priloženih planova summae cavee in ligneis ${ }^{4}$, više od jedne polovice konstrukcije našeg Amfiteatra bilo je na četvrtoj i petoj etaži izvedeno u drvu, dok neki detalji vezivanja kamenih blokova na stubišnim tornjevima također podsjecaju na drvene konstrukcije jer su vezani poput drvenih greda.

U vezi s proučavanjem Koloseuma zanimljiva je tvrdnja jednoga od proučavatelja izvornoga stanja njegovih suterenskih etaža, za koje Beste tvrdi da nisu nikada adekvatno analizirani i proučeni, te da je to vrlo čudno. ${ }^{5} \mathrm{Uz}$ pisane, tvrdi Beste, potrebno je proučiti i analizirati arhitektonske strukture, a to se može učiniti samo putem precizne i pedantno učinjene arhitektonske snimke u kojoj ce biti obuhvaćeni i registrirani svi relevantni detalji (SI. 2.). ${ }^{6}$

Ovim cu tvrdnjama dodati: kada se gleda, onda se mora i vidjeti. Nema velikih i malih nalaza, svi su važni; svi koji se mogu povezati u nekom jedinstvenom izvornom funkcionalnom sklopu. Primjerice, onako kako se spajaju dijelovi razbijene vaze (lonca), što je relativno lak zadatak, dok je zgrada slojevita pa za njezino spajanje treba više znanja jer ima više različitih materijala i funkcionalnih dijelova. Često je to posao poput kirurga koji povezuje dijelove smrskane šake da ponovno proradi i služi prvotnoj izvornoj funkciji. Početke toga posla u graditeljskom naslijeđu učio sam od prof. dr. Jerka Marasovica tijekom 1970-ih.

Durm brižljivo opisuje vijence. Velarij ne rješava, osim navođenja da su mornari bili tijekom igara stalno zauzeti. Dopunjeni presjek na stranici 691. u svim je detaljima neprihvatljiv!7 Uglavnom se bavi ukrasima, dok je njegovo datiranje posve neprihvatljivo. Od svih Izenorovih prezentiranih velarija ${ }^{8}$ jedan jedini koji donekle 'drži vodu' jest onaj koji je učinio Stancovich P. 1822. godine (Tafel 147/3) na temelju opisa što ga je dao Carli G. godine 1793. u svojoj studiji o pulskom Amfiteatru. ${ }^{9}$

Godine 1728. Scipione Maffei izdaje knjigu o veronskom Amfiteatru ${ }^{10}$, u kojoj posvecuje jedno poglavlje studiji velarija iz koje saznajemo da je za izradu idejnog projekta angažirao arhitekta Carla Fontanu (1618.-1714.), jednoga od četiriju glasovitih arhitekata iste obitelji podrijetlom iz švicarskog kantona Ticino u 16. i 17. stoljecu. Oni su se isticali svojim djelima u tehničkim, ali i u vecem broju funkcionalnih intervencija usklađivanja urbanoga tkiva Rima. Njihova istraživanja klasične ravnoteže i jasnoce kompozicije bila su konstanta arhitekture Carla Fontane, koji svojim djelima utječe na svoje sljedbenike, među kojima su Fischer von Erlach i Hildebrandt u Austriji, Gibbs u Engleskoj i Pöppelmann u Njemačkoj. Kao što vidimo, Fontana se potkraj života bavi i velarijem Amfiteatra u Veroni $^{11}$, kada postaje i nasljednik Berninija zadužen kao papinski arhitekt. ${ }^{12}$

U kračm pregledu učinjenih idejnih rješenja, od kojih su samo neka unaprijedila znanja o velarijima i o izvornom izgledu Amfiteatra, navest cemo i onaj koji je 1714. arhitekt Carlo Fontana predložio Scipioneu Maffeiju za Amfiteatar u Veroni, a koji po nekim konstrukcijskim elementima sliči našemu konačnom prijedlogu za pulski Amfiteatar, kao rijedak primjer uopce (Sl. 5.). Maffei tvrdi da se u veronskom Amfiteatru iznad gledatelja prostirao velarij koji su Rimljani nazivali vela i velaria (u pluralu).

Kao dokaz o korištenju velarija on navodi nalaz manje mramorne ploče s tanjim izbrušenim kanalicima koji su učinili tanji potezni i razvlačivi konopi, ne deblji od $1 / 4$ mletačke unce $(0,72 \mathrm{~cm})$, kojima su vojni mornari namještali jedra na svoja mjesta, određena debljim zateznim nosivim konopima fiksirane dužine. Osim ovih tvrdnji o velariju, Maffei postavlja pitanje na koji su se način jedra mogla dignuti na tu visinu, pa su za rješenje toga angažirani Architetti di Roma, predvođe- 

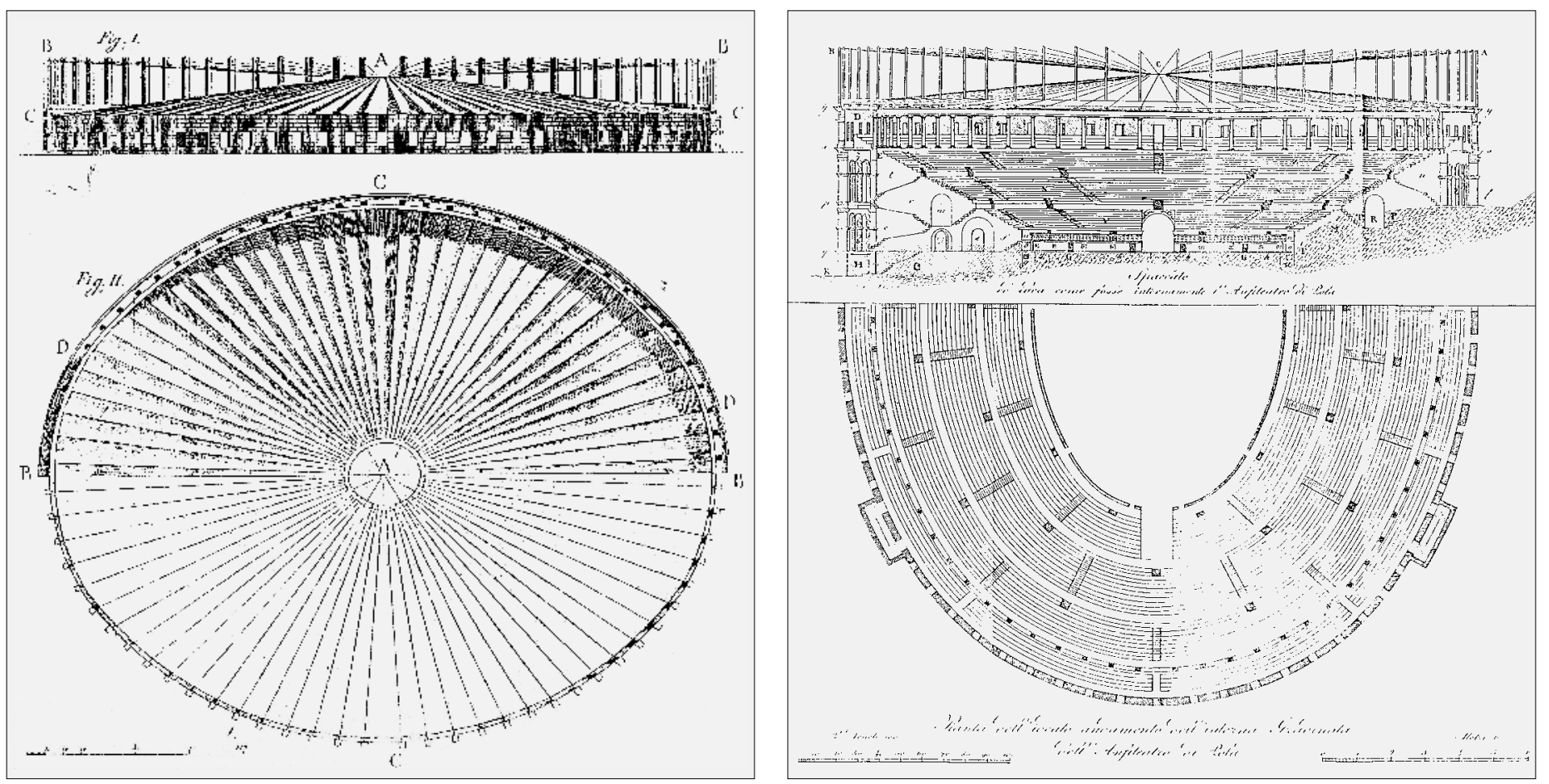

ni vjerojatno C. Fontanom, koji nije riječima objasnio kako se može učiniti takav sustav, vec je izradio samo nacrt, odnosno tlocrt svih nosivih konopa. Šteta što nije učinio i poprečni presjek, u krupnijem mjerilu, ali i bez njega je razvidno kako je izgledao velarij i kako ga se moglo koristiti, po potrebi dignuti u otvorenom i zatvorenom položaju, s time da se ne pokrije prostor ponad arene. Ovalni prsten koji je dosezao do ravnine ruba borilišta (arene) morao je biti jako debeo kako bi izdržao zateznu silu svih konopa nosača jedara: (...)

1 Velum (lat.), velario (tal.) - tenda koja je pokrivala teatre i amfiteatre kako bi gledatelje zaśtitila od sunca i oborina. U početku od običnog lana, poslije od najfinijega lanenog platna i svile.

2 KRIZMANIĆ, 2016: 132-155

3 REA, 2001: 69-77

4 Summa cavea in ligneis (lat.) - najviši dio gledališta u drvu

5 BESTE, 2001: 277

6 BESTE, 2001: 278

7 DURM, 1905.

8 IZENOUR, 1992: Tafel 147/3

9 CARLI, 1793: 219-226

10 MAFFEI, 1728: 290-287

11 MAfFeI, 1728: 294-295, Tav. XII.

12 PeVsner i dr., 1992: 220; *** 1973: 230

13 LUCIANI, 2000: 82-86 i 103-106. Za sagraditi Amfiteatar trebalo je raspolagati s jednom brojnom specijalizira nom radnom snagom. Aproksimativno se może predvidjeti da je na gradilištu bilo dnevno od 500 do 1000 radnika raznih struka. Za transport glomaznih blokova materijala $u$ Rimu su se gradile posebne ceste. U Puli se za prijevoz koristilo more od raznih kamenoloma duż obale ili blizu mora jer je lokacija Amfiteatra bila blizu morske obale u dobro zašticenom zaljevu.
SL. 3. INŽINJER R. SBISÀ 1788. ZA G. CARLIJA, PRIJEDLOG VELARIJA ZA PULSKI AMFITEATAR: NEPRIHVATLIIVO

FIG. 3 ENGINEER R. SBISÀ, 1788, FOR G. CARLI, PROPOSAL FOR THE VELARIUM OF THE VERONA AMPHITHEATRE: UNACCEPTABLE

anello ovale di grossa fune (...). Zbog toga je naše rješenje sa sličnom kombinacijom konopa napušteno. Različito je interpretirana i površina na kojoj je 400 do 500 majstora radi$\mathrm{lo}^{13}$, izvodilo summa cavea in ligneis i velarij,
SL. 4. KANONIK P. StANCOVICH 1822.: MANJIM DIJELOM PRIHVATLJIVO

Fig. 4 CANon P. Stancovich, 1822: ACCEPTABle TO A LESSER EXTENT

Sl. 5. Arhitekt C. Fontana 1714. ZA S. MaffeiJa, PRIJEDLOG VELARIJA ZA VERONSKI AMFITEATAR: DIJELOM PRIHVATLIIVO

Fig. 5 Architect C. Fontana, 1714, For S. Maffel, PROPOSAL FOR THE VELARIUM OF THE VERONA AMPHITHEATRE: PARTIALLY ACCEPTABLE

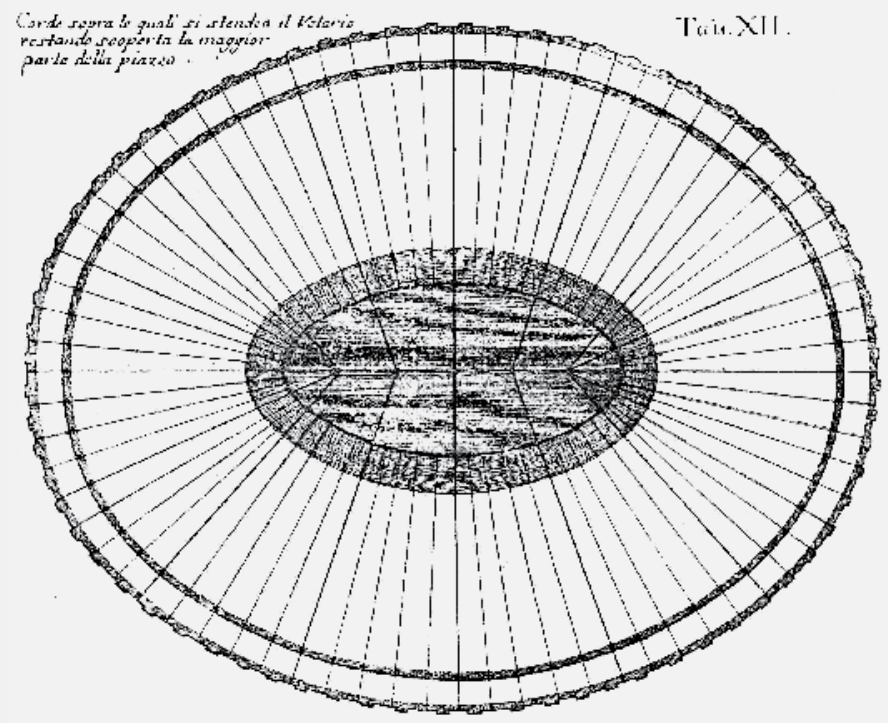



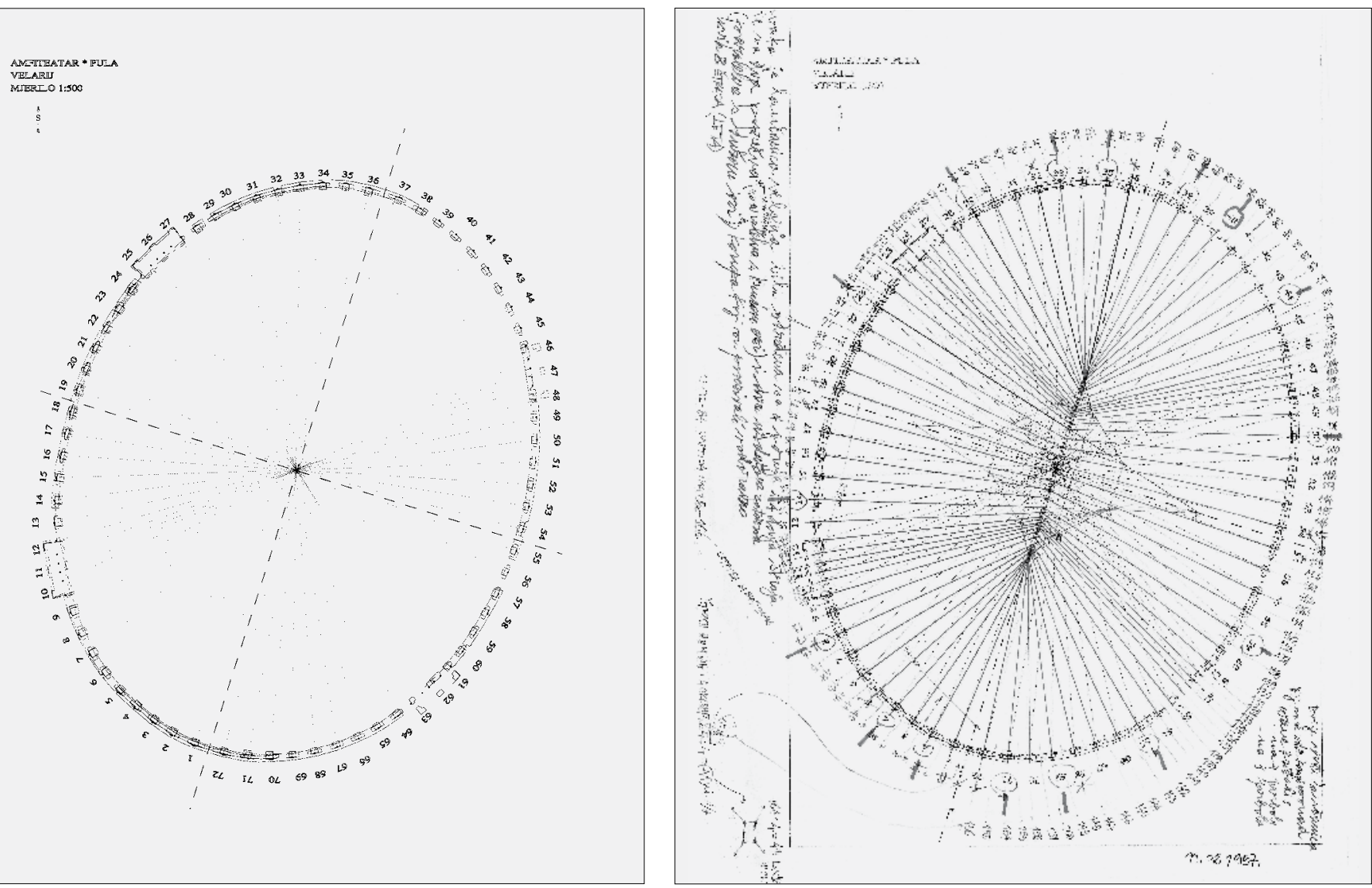

SL. 6. RASPORED LETA U SREDIŠNJOJ TOČKI U KOJOJ SE SIJEKU VELIKA I MALA OS: NEPRIHVATLJIVO U SUSTAVU VELARIJA

FIG. 6 ARRANGEMENT OF BACKSTAYS AT THE CENTRAL POINT WHERE THE BIG AND SMALL AXES INTERSECT: UNACCEPTABLE IN THE VELARIUM SYSTEM

SL. 7. SUKLADNI RASPORED SVIH DONJIH NOSIVIH (92) I SVIH GORNJIH ZATEZNIH (92), UKUPNO:

184 ŠTRAJA (LETA): DJELOMIČNO PRIHVATLJIVO KAO RJEŠENJE VELARIJA

FIG. 7 CONSISTENT ARRANGEMENT OF ALL LOWER BEARING (92) AND ALL UPPER TENSIONING (92), TOTAL: 184 BACKSTAYS: PARTIALLY ACCEPTABLE AS A VELARIUM SOLUTION počevši od korištenja površine arene (borilišta) i završivši na tri palube: glavnoj, gornjoj (paluba kavaleta) i palubi kaštela. Nije prihvatljivo da tijekom izvođenja ovih radova majstori različitih zanata hodaju po gornjem rubu suženoga vijenca (70 do $80 \mathrm{~cm}$ širine). Ne radi se samo o sigurnosti hodanja i lakih padova s $30 \mathrm{~m}$ visine, već i o površini koja je potrebna za izvođenje, pripremu, složeno korištenje i manevriranje velarijem. Ovu površinu ne spominje ni Maffei ni arhitekt Carlo Fontana.

Gianrinaldo Carli posjetio je Pulu u dva navrata radi proučavanja, pored ostaloga, i Amfiteatra. Prvi put 18 . lipnja 1750 . godine u pratnji Vitaliana Donatija, profesora povijesti, botanike i prirode, te crtača Francesca Monaca, odličnoga bakroresca. Pri drugom je posjetu Puli Carli bio zajedno s inžinjerom Roccom Sbisà, i to od 11. studenoga do 13. prosinca 1788. godine (Sl. 3.). Carli se pita kako se tako prostrani 'tendone' mogao otvoriti i poduprijeti. To je problem koji znanstvenici još nisu bili riješili. Arhitekt Fontana je priložio lijep crtež a da nije riješio rub i način na koji ce se velarij dignuti u sredini i stvoriti pad prema vanjskim rubovima kako bi se pomoglo vodi da iscuri kroz rupe ('rigalice') u vijencu. Za rješavanje tog problema Carli uzi- ma klupice - 'panchine' i koloture u sredini na kraju 72 konopa, kojih krajeve provlači, nateže kraj koloture i veže na dva reda kamenih blokova iznad vijenca na 'panchine'. U potezanju ovih konopa koloturama na jarbolima postupno se podizao velarij u njegovoj sredini i tako se stvarao stožac s podom prema donjim rubovima velarija kako bi se prikupljala i otjecala voda kišnice. Kako cemo vidjeti: tako nije bilo, a nije ni moglo biti. To cemo pojasniti kada cemo obrazložiti rad 'našega' velarija.

U Carlijevu velariju nema spomena zategama (štrajima ${ }^{14}$ ) koji su se vezivali za vrh jarbola, dva štraja na 2 kamena bloka od 4 tone svaki, ugrađeni u okoliš na udaljenost od $10 \mathrm{~m}$ do $18,50 \mathrm{~m}$. Gotovo siguran u pravilnost svojega rješenja, Carli daje upute inžinjeru Sbisà da nacrta tlocrt i presjek Amfiteatra s velarijem. Mora se primijetiti da se svi konopi velarija ne sijeku u križanju velike i male osi Amfiteatra, nego da svaka cetvrtina tlocrta ima svojih 5 sukladnih centara zakrivljenosti (SI. 6.-10., 12., 14.), tako da su svi konopi okomiti na tangentu svojega dijela policentrične krivulje. Isto tako, Carli ne poznaje površine Amfiteatra, na kojima nekoliko stotina majstora svojih zanata gradi summu caveu in ligneis i velarij, pa se tako velarij protegnuo do 

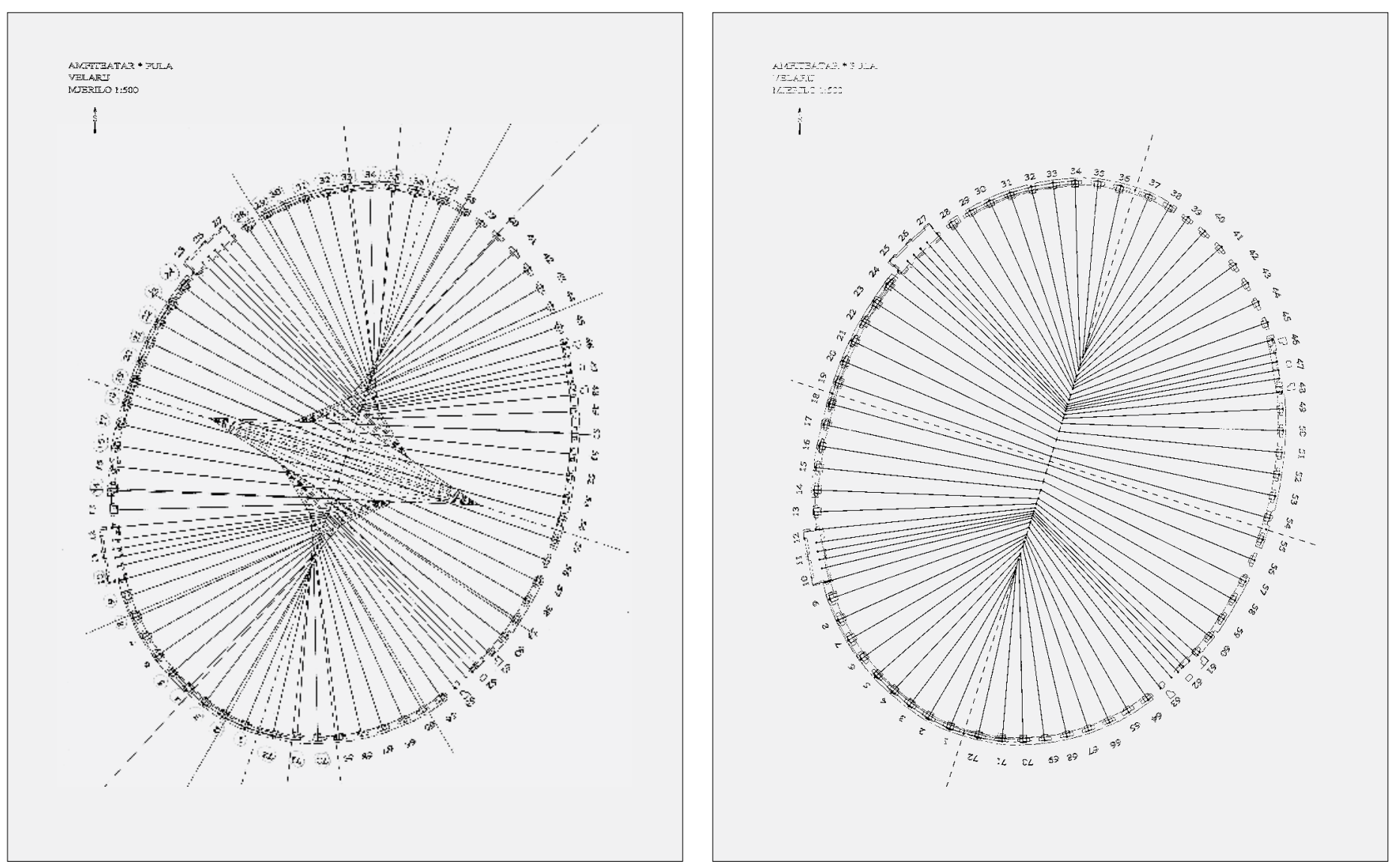

jarbola antemnae. ${ }^{15}$ Carli nije objasnio kako je moglo nekoliko stotina majstora raznih zanata, potom i mornara, stajati na uskome prostoru ponad, između užlijebljenog vijenca i klupice ('panchette'). Međutim, dobro je zaključio kako je velarij bio učinjen od više dijelova, jer ga se u pisanim izvorima uvijek spominje u pluralu (množini) = vela - velorum, nikad velum ili velarium, te izraden redovito od finog lana ili svile. Carli navodi da je osim mreže nosivih zateznih konopa svako jedro imalo dva tanja konopa = ghindazza, kojima su se pojedina jedra smještala na svoje mjesto (funicelle doppie = dupli tanji konopi), s preklopom jedara tako da voda ne prodire između njih.

Kako voda ne bi prodirala u Carlijevoj sredini s dodatnim željeznim obručom, on zamišlja da se u tom sjecištu učini jedna vrsta kišobra-

14 Štraj, strallo ili straglio (tal.) - leto (hr). Izuzetan dio konopa, lancanica velarija. Gornji štrajevi na lançanici zateżu se koloturima na jarbole kako bi donji štrajevi vezani za bitve bili nagnuti za $11^{\circ}$ u odnosu na ravninu glavne palube (na $35.95 \mathrm{~m} / \mathrm{n}$.v.), po kojima se zateżu i rasteżu 92 jedra od glavne palube do $31 \mathrm{~m}$ iznad borilista - arene. Osnovni konopi raznih profila i čvrstoce koji čine 23 lanćanice po kojima se razvlače i povlače jedra.

15 Antemna (lat.), antena, jarbol broda

16 Archeografo Triestino, sere III., vol. XIII: 143-346, 351356 , Trieste na koji bi zatvorio taj još nepokriveni dio velarija. Međutim, jači vjetar mogao je remetiti igre i odnijeti kišobran, pa Carli navodi izvjesnog Agabina koji je usprkos vjetru provodio svoje igre. Na kraju Carli s velarijem priziva u pomoc mornaričku vojsku, koja je bila vična tome svakodnevnom poslu pa ce najlakše privesti kraju tu svojevrsnu mrežu konopa s izrazitim progibima. Štoviše, „ako se niti prejasni Vitruvije nije usudio opisati velarij”, tvrdi Carli, „,bila bi neoprostiva umišljenost da smo mi to proniknuli učiniti”.

Arhitekt Pietro Nobile, Švicarac rođen također u kantonu Ticino, bio je u Puli više puta (od 1809. do 1818.), napisao je izvješce o svojim istrażivanjima pulske antike, ali nije uspio načiniti namjeravanu studiju izvornoga stanja Amfiteatra. On postaje arhitekt carskoga dvora Franje I., a velarij samo sporedno spominje, ali ne ulazi u rješavanju detalja, navodi ga tek zajedno $s$ našom glavnom palubom kao „ripiano del velario”. Pietro Nobile bio je poznat u doba Austrije, a manje u talijansko doba, no nakon 1945. godine njegov je rad u Puli i na tlu hrvatskoga Jadrana bio otkriven u opširnom članku Livije Rusconi iz 1926.: Pietro Nobile e i monumenti romani di Pola. ${ }^{16}$ Kod nas se 1988. godine o njemu pisalo u dva znanstvena rada: Komunalna palača - Pula
SL. 8. SUKLADNI RASPORED SVIH DONJIH I GORNJIH ŠTRAJEVA: DJELOMIČNO PRIHVATLJIVO KAO RJEŚENJE VELARIJA

FIG. 8 CONSISTENT ARRANGEMENT OF ALL LOWER AND UPPER BACKSTAYS: PARTIALLY ACCEPTABLE AS A VELARIUM SOLUTION

SL. 9. SUKLADNI RASPORED SVIH ŠTRAJEVA (LETA): DJELOMIČNO PRIHVATLJIVO KAO RJEŠENJE VELARIJA FIG. 9 CONSISTENT ARRANGEMENT OF ALL BACKSTAYS: PARTIALLY ACCEPTABLE AS A SOLUTION FOR THE VELARIUM 


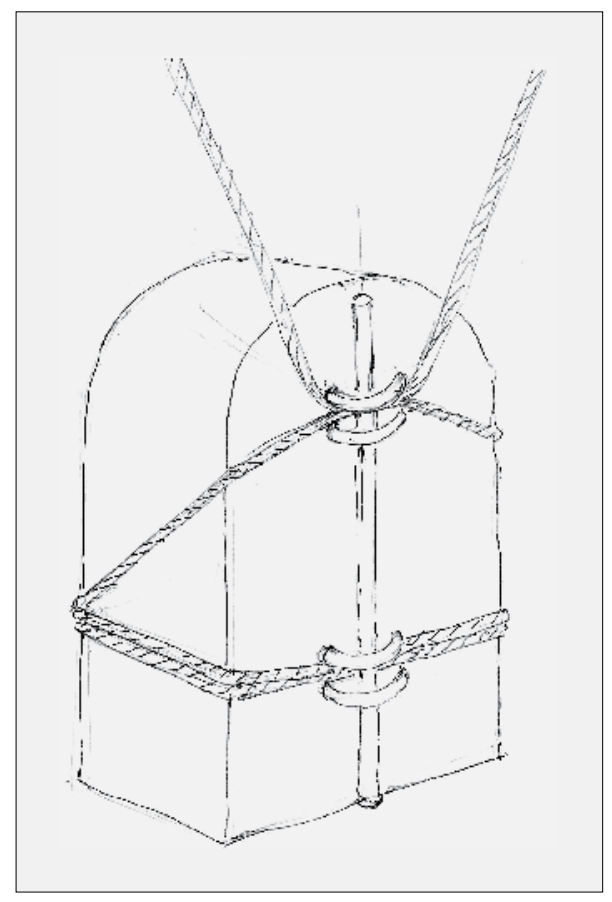

Sl. 10. Alternativno RJeŠEnje zateznog cipusa DO KOLOSEUMA

Fig. 10 Alternative SOlution: A tensioning Cippus TO THE ARENA

SL. 11. Prostorna SKICA SLOŻene LANČanice NA 4 JARBOLA

Fig. 11 SPATIAL SKETCH OF THE COMPLEX CATENARY ON 4 MASTS

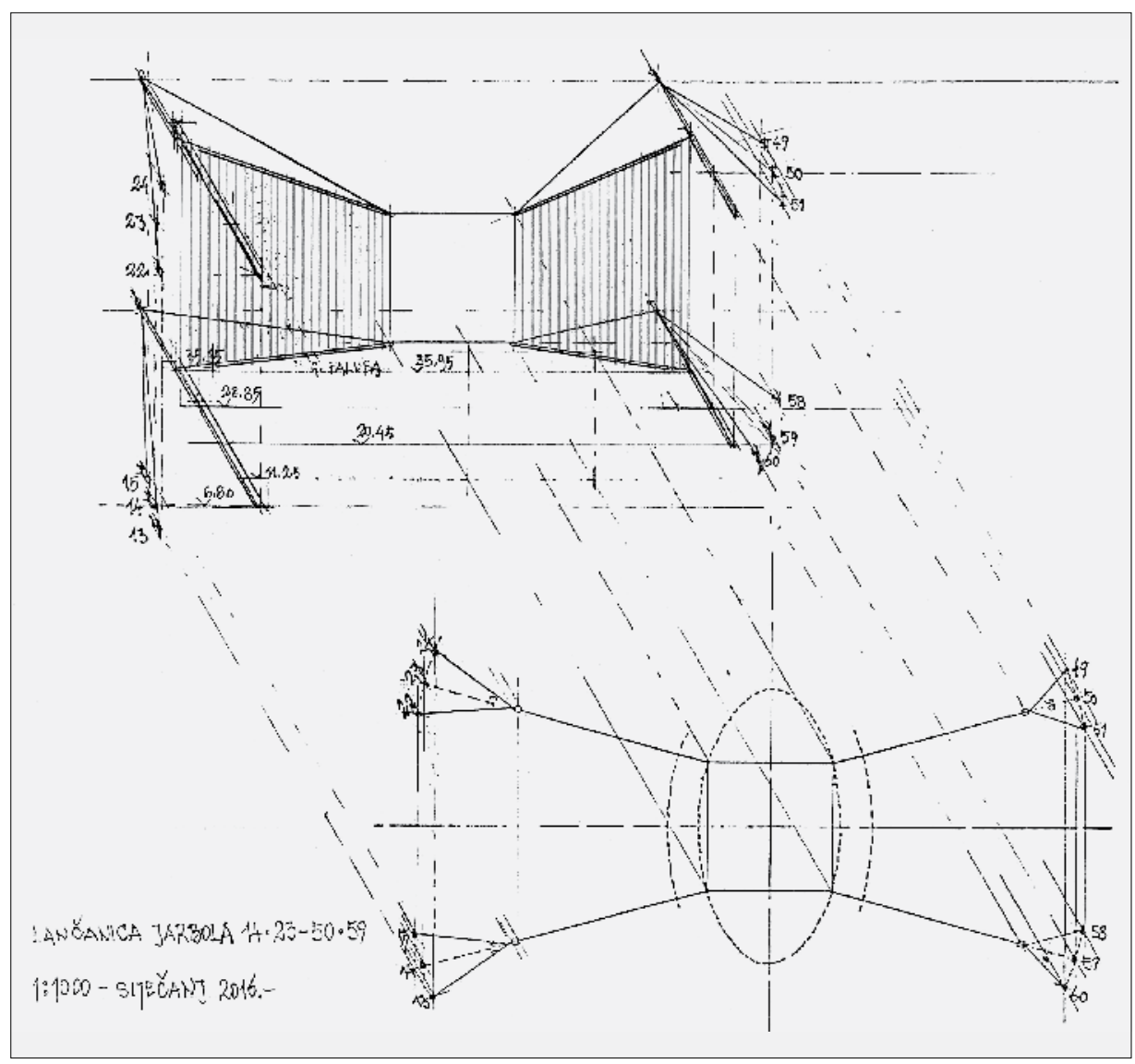

A. Krizmanica i u članku o radu Pietra Nobilea prigodom posjeta Puli 1814., 1816. i 1818. godine. ${ }^{17}$

Barbanski kanonik Pietro Stancovich objavio je 1822. godine knjigu o cjelovitoj studiji pulskog Amfiteatra, po kojoj slijedi u svemu ideju velarija koju je 1793. objavio Gianrinaldo Carli, a koja je po Stancovichu dotad najbolje rješenje (danas s mojim primjedbama, SI. 4.). ${ }^{18}$ Kako bi mogla početi izrada velarija, trebalo je najprije komentirati izvedbu i montažu palube s jarbolima, a potom prikaz kako vidim summu caveu in ligneis, svakako u drvu, a ne u kamenu. Predmet je ovoga rada objasniti kako je bio sastavljen i kako se koristio velarij u zaštiti gledatelja od jakog sunca i kiše. Zašto palube, a ne krov? Ne zato da budem originalan ili zbog autentičnosti, vec iz potrebnoga radnog prostora na četvrtoj i petoj etaži na kojem ce se stvarati, sastavljati i montirati velarij, od razine glavne palube $(35,95 \mathrm{~m} / \mathrm{n} . v$.$) do palube kaštela (40,00$ $\mathrm{m} / \mathrm{n} . \mathrm{v}$.), iz koje se upravlja svim poslovima stvaranja veluma. Vojni mornari - kada dižu, a potom i upravljaju jedrima - moraju imati slobodan prostor gornje i glavne palube. $\mathrm{Ne}$ može se širinu završnog vijenca $(70-80 \mathrm{~cm})$ svesti na površinu za sastavljanje i manevriranje velarijem, s posadom katkad i do 400 mornara, spremnih uvijek na brzo razvijanje i skupljanje jedara (SI. 6.-9.).

NAŠ PULSKI VELARIJ, 2020.

\section{VELARIUM IN PULA'S AMPHITHEATRE, 2020}

lako su drvena stubišta u našem Amfiteatru kom u razini II. cirkularnog hodnika (na 20.45 $\mathrm{m} / \mathrm{n} . \mathrm{v}$. ), početak summae caveae in ligneis smjestio sam od razine III. cirkularnog hodnika (na $28.85 \mathrm{~m} / \mathrm{n}$.v.) sa svim debljim nosivim gredama koje su ležale na izbočini cirkularnog zida preko podsponjaka - 'spavača'. Na III. cirkularnom hodniku ispod trijema glavne palube sjedile su žene i promatrale igre iz improviziranih daščanih konstrukcija.

Kako bi se moglo organizirati učinkovito stvaranje velarija, moralo se najprije završiti cjelovitu kamenu i drvenu konstrukciju na četvrtoj/petoj etaži, tzv. summu caveu in ligneis, istodobno $s$ dovršenjem četiriju stubišnih tornjeva $\mathrm{s}$ deset drvenih ukrižanih stubišta; sa završnom drvenom palubom kaštela na

17 Krizmanić, 1988.; MARASOVIĆ i dr., 1988.

18 StANCOVICH, 1822: 63-64 smještena u stubišnim tornjevima s prvim kra- 

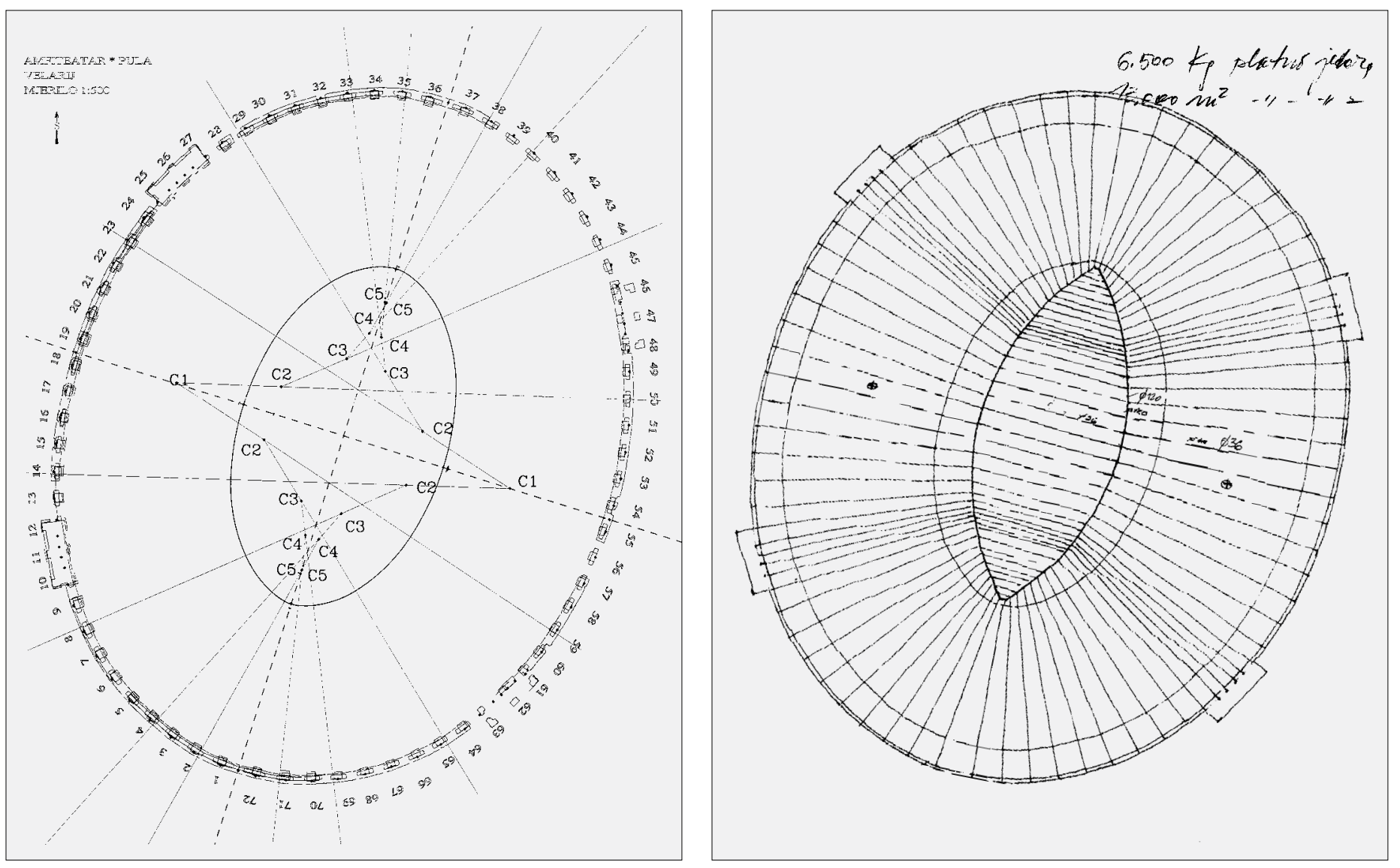

koti 40,00 m/n.v.; s gornjom palubom na koti $38,73 \mathrm{~m} /$ n.v.; s glavnom palubom i užlijebljenim vijencem na koti $35,95 \mathrm{~m} /$ n.v. i 35,80 $\mathrm{m} / \mathrm{n} . \mathrm{v}$. Na navedenim razinama u pripadajucim površinama stvarao se i sklapao, a potom i upravljalo velarijem.

Glavnih nosača velarija ukupno je bilo 84 jarbola (68 jarbola po $30 \times 30 \mathrm{~cm}$ i 16 jarbola po $18 \times 20 \mathrm{~cm}): 68+16=84$ jarbola ili $72+12=84$,

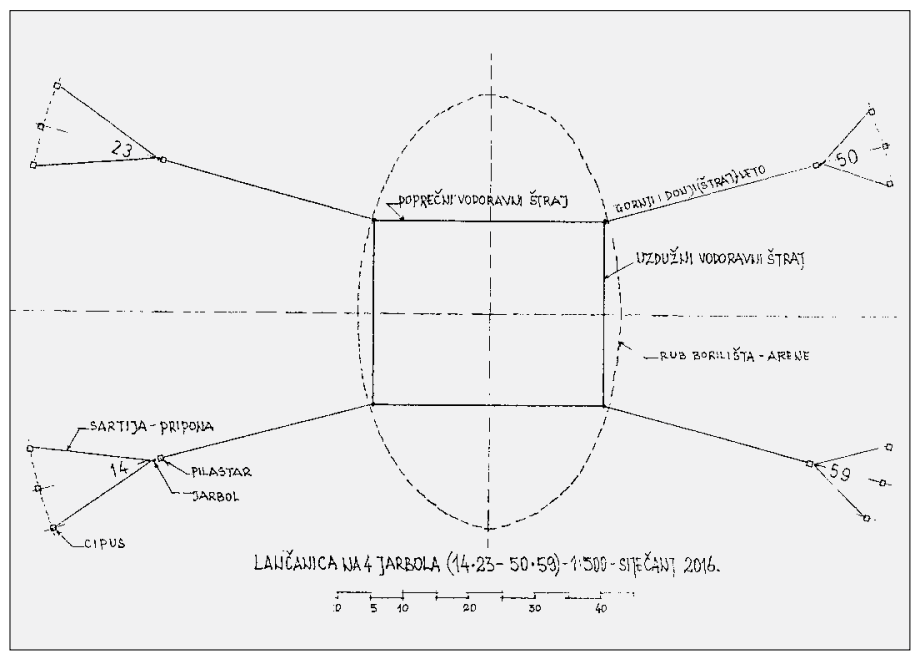

SL. 12. DEFINITIVAN RASPORED 4 SKUPINE PO 5 SUKLADNIH CENTARA ZAKRIVLJENOSTI, PREMA STUDIJI KOJU JE UČINIO GEODET VENCESLAO KRIZMANICH

FIG. 12 FINAL ARRANGEMENT OF 4 GROUPS OF 5 CONGRUENT CENTERS OF CURVATURE ACCORDING TO A STUDY MADE BY THE SURVEYOR VENCESLAO KRIZMANICH

SL. 14. SLOŻEna LANČANICA Na 4 JaRbola, SVAKa u SVojoJ CEETVRTINI AMFITEATRA

FIG. 14 COMPLEX CATENARY ON 4 MASTS, EACH IN ITS OWN QUARTER OF THE AMPHITHEATRE
SL. 13. NEPRIHVATLJIVO - NAJVIŠE ZBOG JAČE DEBLJINE SREDNJIH DVAJU KONOPA I NEPOSTOJANJE RADNE POVRŠINE NA PALUBAMA

FIG. 13 UNACCEPTABLE - MOSTLY DUE TO THE TWO THICK CENTRAL ROPES AND ABSENCE OF WORK SURFACE ON THE DECKS

SL. 15. ANALIZA PROGIBA KONOPA KOMPLEKSNE LANČANICE NA 4 JARBOLA

FIG. 15 ANALYSIS OF DEFLECTION OF THE COMPLEX CATENARY ROPES ON 4 MASTS

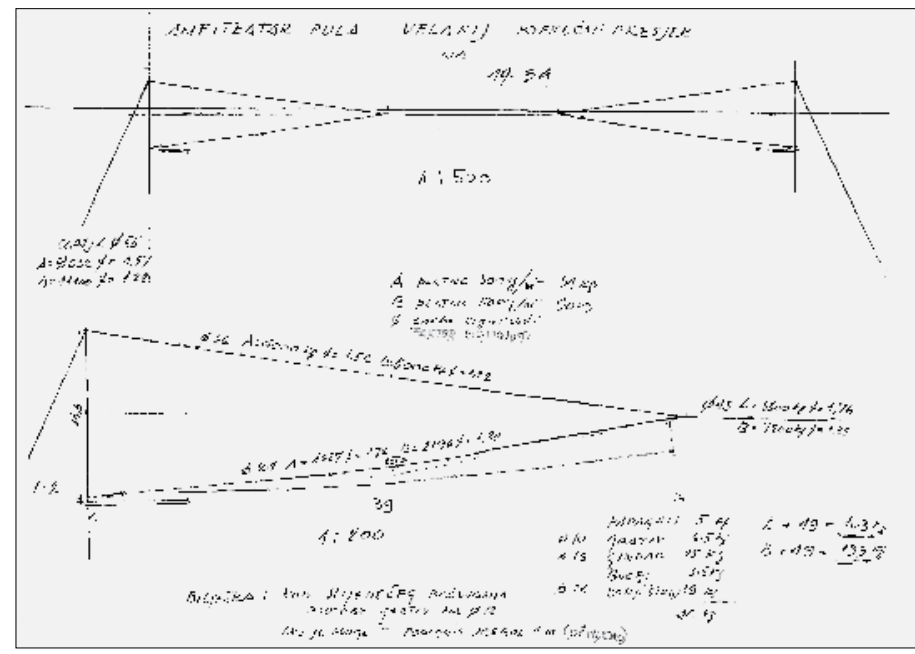




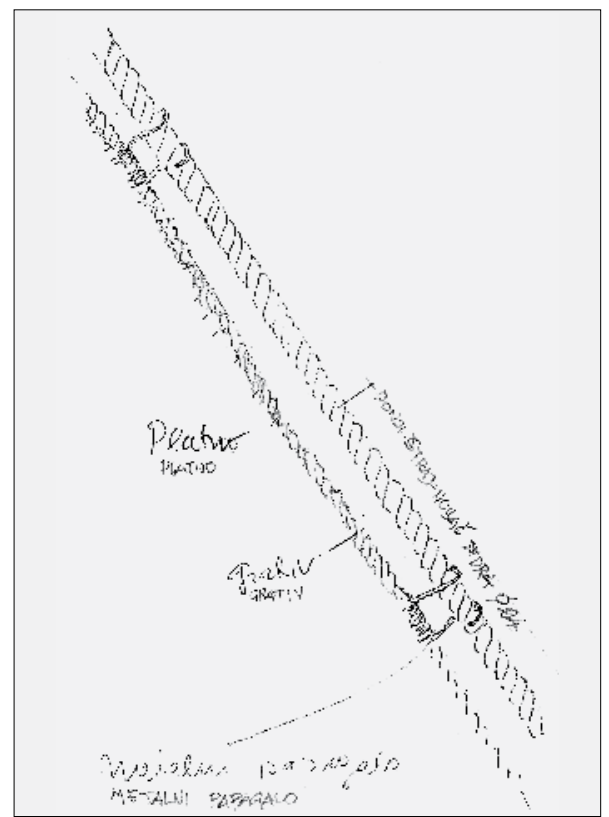

SL. 16. DJELOMIČNA BITNA OPREMA JEDARA VELARIJA FIG. 16 PARTIAL EQUIPMENT OF THE VELARIA SAILS

\section{SL. 17. JARBOL S UGRADENIM LJESTVICAMA} FIG. 17 MAST WITH BUILT-IN LADDERS

\section{SL. 18. VRH JARBOLA S BUCELIMA}

FIG. 18 TOP OF THE MAST WITH TACKLES

SL. 19. SPOJ UZDUŽNIH I POPREČNIH VODORAVNIH KONOPA S GORNIIM I DONJIM ZATEZNIM ŚTRAJEVIMA (LETIMA) TE S BUCELOM GINDACA

FIG. 19 LONGITUDINAL AND TRANSVERSE HORIZONTAL ROPES TIED TO THE UPPER AND LOWER TENSIONING BACKSTAYS AND TO THE HALYARDS' TACKLE

SL. 20. Potpuna oprema Jedara u RAdu VelariJa FIG. 20 FULL EQUIPMENT OF THE VELARIUM SAILS IN OPERATION

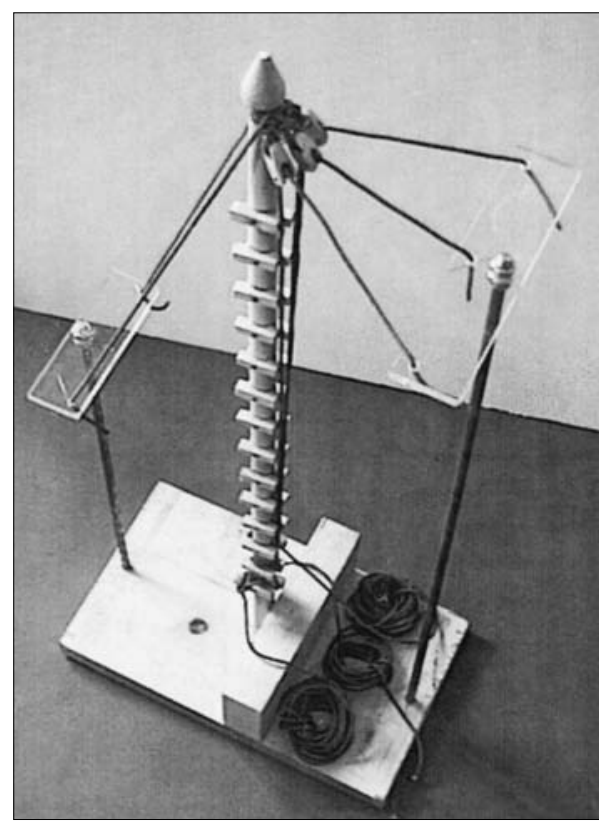

a ne 72 kako se često navodi. Velarij su činile 23 složene lančanice, svaka zategnuta (razapeta) na 4 sukladno zategnuta jarbola; 23 složene lančanice nosile su isto toliko jedara približno jednake veličine $23 \times 4=92$ jedra, svako jedro oko $130 \mathrm{~m}^{2}(5 \times 26 \mathrm{~m})$. Ni oni koji su bili na vrhu tornjeva 10-11-12 i 46-47-48 nisu vidjeli jasne tragove prolaza i ležajeve četiriju drvenih stupova manjeg profila koji su stajali između bačvastih cisterni. Svaki stubišni toranj bio je osobito arhitektonsko istaknuto tijelo na 40,00 m/n.v., jedna vrsta promatračnice iz koje se upravljalo svim radovima u određenoj četvrtini Amfiteatra.

Svaka je lančanica velarija bila određena s 4 gornja zatezna i 4 donja nosiva štraja (leta), te s dva poprečna i dva uzdužna zatezna konopa koji su vodoravno povezivali svih 8 štraja u jedinstven usklađeni statički sustav. Sta-

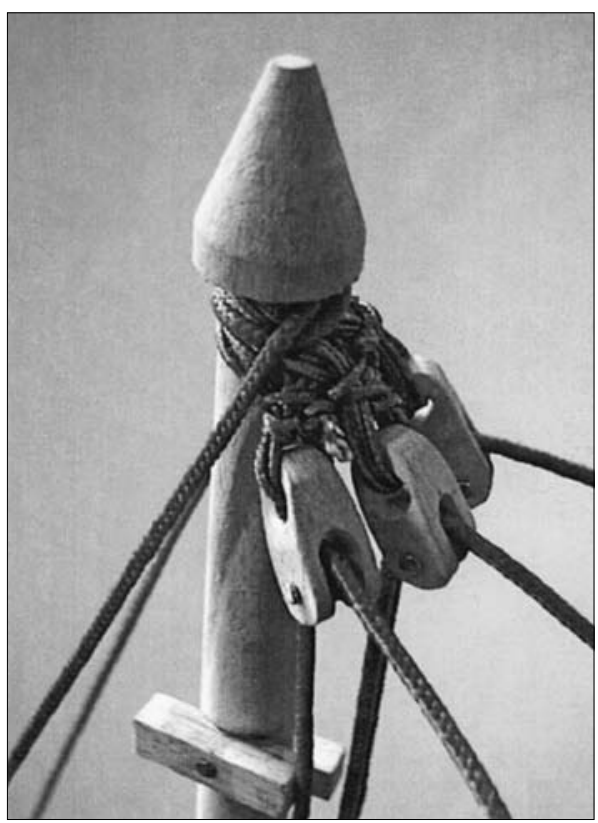

bilitetu toga sustava bitno su pridonosili kameni cipusi ${ }^{19}$ od oko 4 tone, usidreni u okolni teren, po dva za svaki jarbol (Sl. 10.). Četiri donja štraja nosili su jedra, a 4 gornja zatezna štraja, koji su putem bucela (kolotura) ${ }^{20}$ bili vezani za vrh jarbola, dizali su sredinu velarija i tako stvarali pad jedra (oko $11^{\circ}$ ) prema užlijebljenom vijencu, a kroz rigalice izbacivali vodu u okoliš. Ukupno 92 donja štraja + 92 gornja štraja $=184$ štraja.

0 izvornom stanju Amfiteatra ne može se raspravljati ako ga se prezentira bez velarija ili samo sa zabodenim nosivim jarbolima na predviđene ležajeve u razini vijenca III. cirkularnog hodnika (28,84 m/n.v.). Zato je naš velarij predočen opisima summae cavee in ligneis od trecega cirkularnog hodnika do vrha Amfiteatra, do apsolutne najviše kote palube Kaštela (na 40,00 m/n.v.; Sl. 12.) iz-
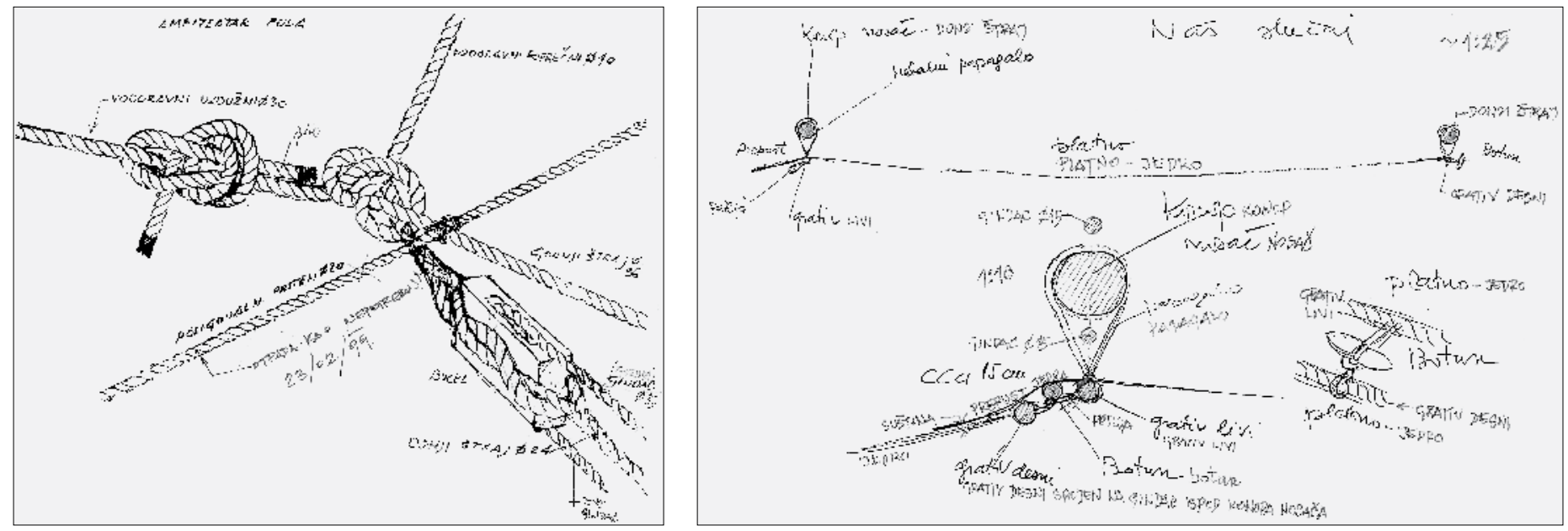


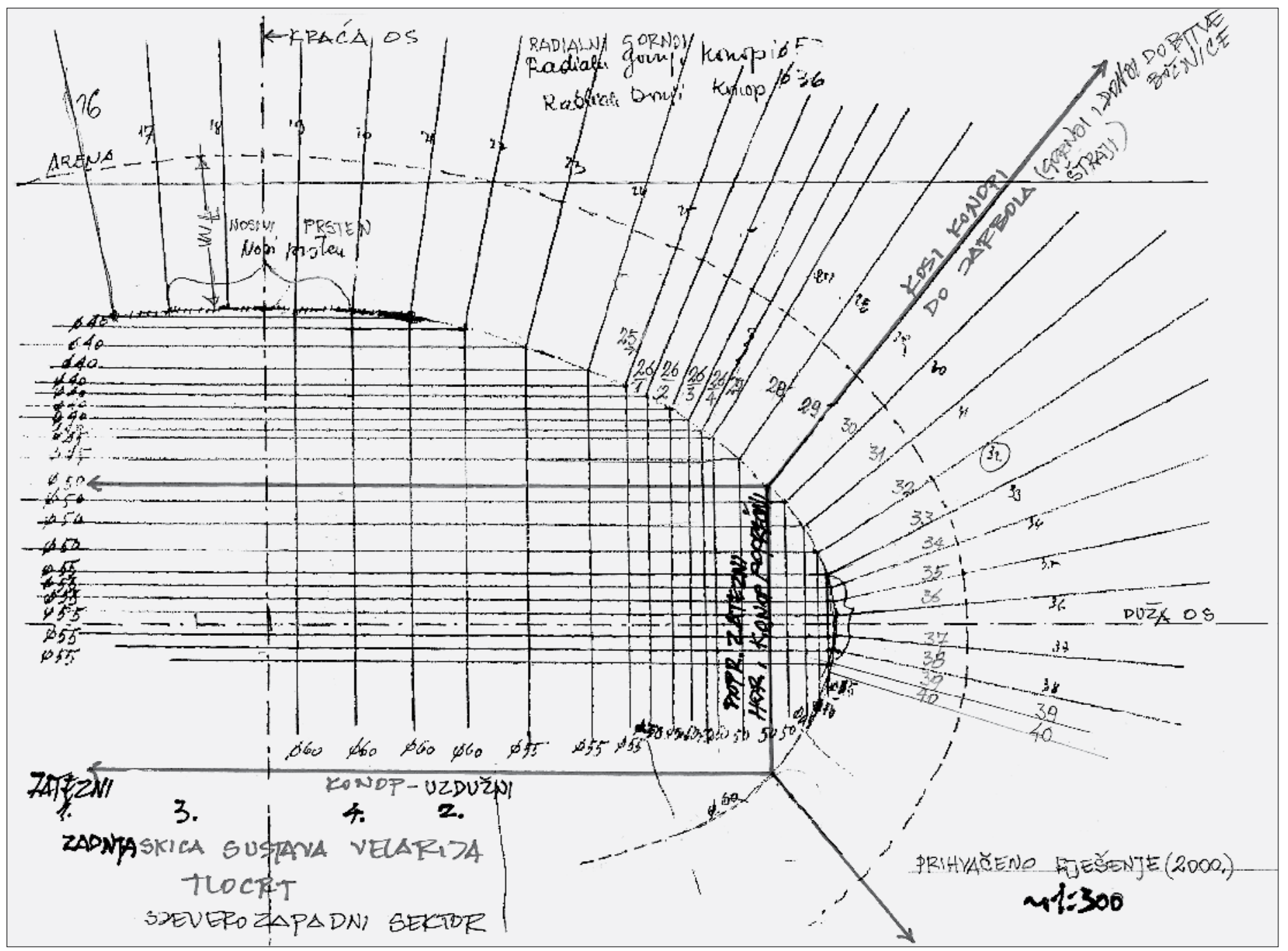

među dvojih vrata kroz koja su na tri palube (Glavna, Gornja ili Kavaleta i Kaštela) izlazili povremeno majstori raznih zanata, a potom na kraju vojni mornari (classiarii) koji su namještali stalne konope, prije spomenute nosive i zatezne, a gindacima ${ }^{21}$ su upravljali jedrima prilagođujuci ih trenutačnim vre-

19 Cipusi, od tal. cippi - veci teški kameni blokovi oko 4 tone, usidreni $u$ teren na 10 do $18 \mathrm{~m}$ od proceljnog zida amfiteatra, na koje su se sidrile po dvije sartije od vrha jarbola do njih.

20 Bucel - kolotura (tal. bozzello, carrucola di specie e funzioni diverse), uređaj za dizanje, premještanje i spustanje tereta te za povlačenje i razvlacenje jedara. Pomična, nepomična i višekraka. Koristila se na više mjesta u gradnji Amfiteatra i u sastavljanju velarija.

21 Gindac (tal. ghindazzo), konopac za dizanje - razvlačenje jedara. Od ghindare: dizati uvis jarbol ili jedro. U našem Amfiteatru to je konop koji je pričvršcen na vrhu (kraj) jedara, a služi za njihovo razvlačenje i povlačenje preko koloture.

22 Papagalo, metalna ili drvena vodilica sašivena na grativ jedra klizeci po donjem štraju, nosaču jedra. Grativ (tal.), gratile, konop, uże; našivak (optok, porubnik) po rubu jedara. menskim uvjetima. Tanji razvlačivi zatezni konopi $\varnothing 24 \mathrm{~mm}$ poteżu jedra gindacima

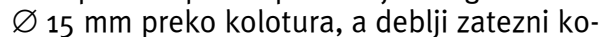
nopi $\varnothing 36 \mathrm{~mm}$ fiksiraju postavu debljih konopa preko kolotura na jarbolu kako bi se dobio pad velarija od oko $11^{\circ}$ (SI. 11. 13.-15., 17.-18.).

Metalni papagali22 tekli su duž nosivih konopa $\varnothing 24 \mathrm{~mm}$ i visjeli na njima pričvršceni na porub jedara (grativ). Konstrukcija iznad III. cirkularnog hodnika pripadala je vecinom u summu caveu in ligneis, učinjenu za potrebu podizanja sustava konstrukcije konopa velarija te za ostvarenje i sklapanje jedara i njihovu jasnu raščlambu na 92 sekcije opremljene papagalima na grativima jedara.

Izrada našeg velarija započinje sastavljanjem i povezivanjem na ravnini arene 23 konopa, odnosno 92 raznih pravokutnih nejednakih kompleksnih dijelova lančanica, kako bi majstori (faberi) potrebnih zanata mogli izraditi i ugraditi 3 drvene palube, osnovnu
SL. 21. SJEVEROZAPADNI SEKTOR SUSTAVA VELARIJA NA POVRŠINI ARENE - BORILIŠTA. SKICA TLOCRTA KONAČNOG RJEŠENJA SMJEŠTAJA UZDUŽNIH I POPREČNIH VODORAVNIH ZATEZNIH KONOPA.

FIG. 21 NORTH-WESTERN SECTOR OF THE VELARIA SYSTEM ON THE SURFACE OF THE ARENA. LAYOUT SKETCH OF THE FINAL POSITIONS OF THE LONGITUDINAL AND TRANSVERSAL HORIZONTAL TENSION ROPES. 


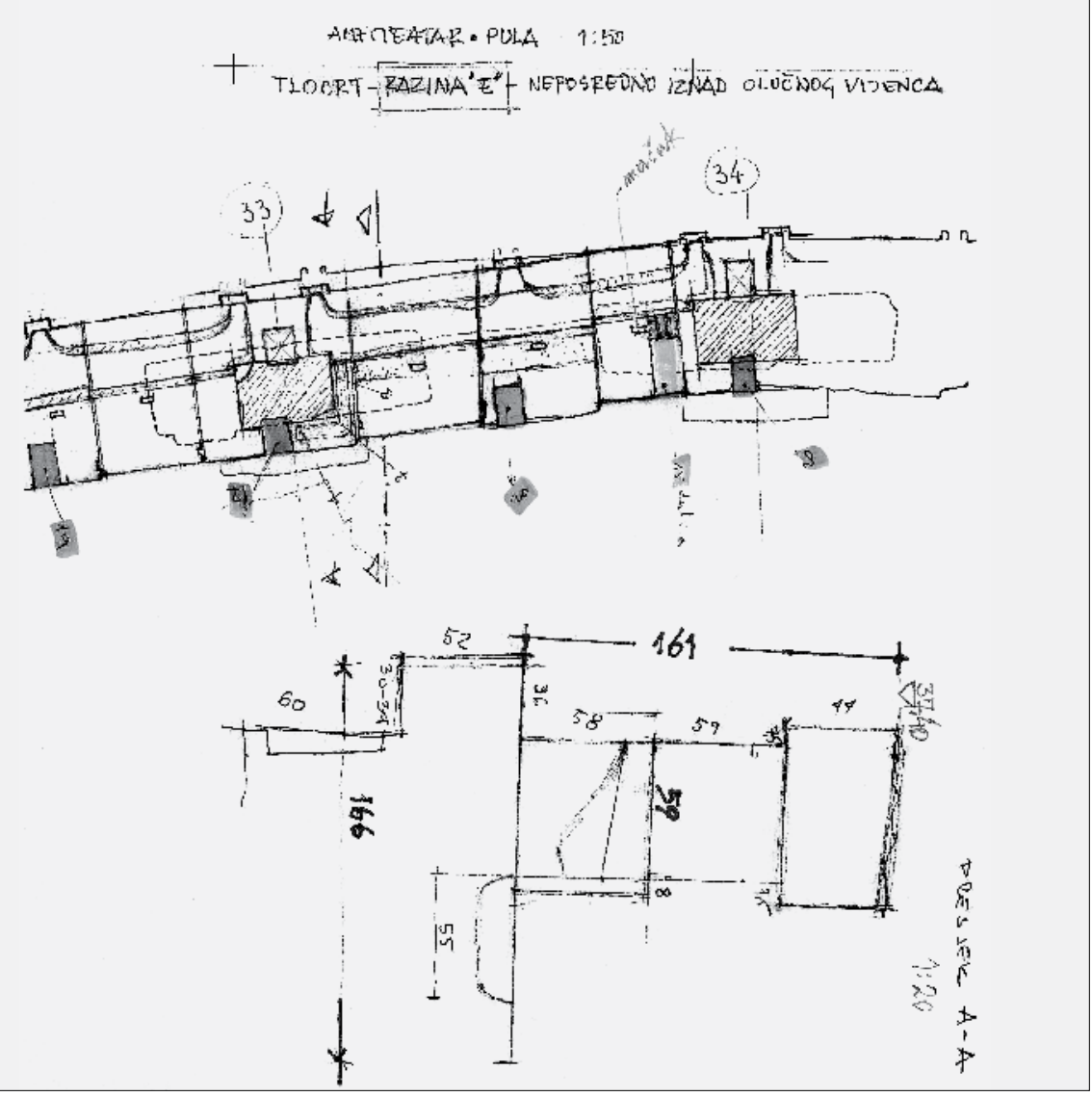

SL. 22. TLOCRT I PRESJEK NA VISINI UŽLIJEBLJENOG VIJENCA I RAZME PONAD VIJENCA DO APSOLUTNE VISINE OD 37,40 M/N.V. NA POZ. 33134

FIG. 22 LAYOUT AND SECTION AT THE HEIGHT OF THE GROOVED CORNICE AND THE RASMA ABOVE THE CORNICE UP TO THE ABSOLUTE HEIGHT OF $37.40 \mathrm{M}$ ABOVE SEA LEVEL ON POSISTIONS 33 AND 34

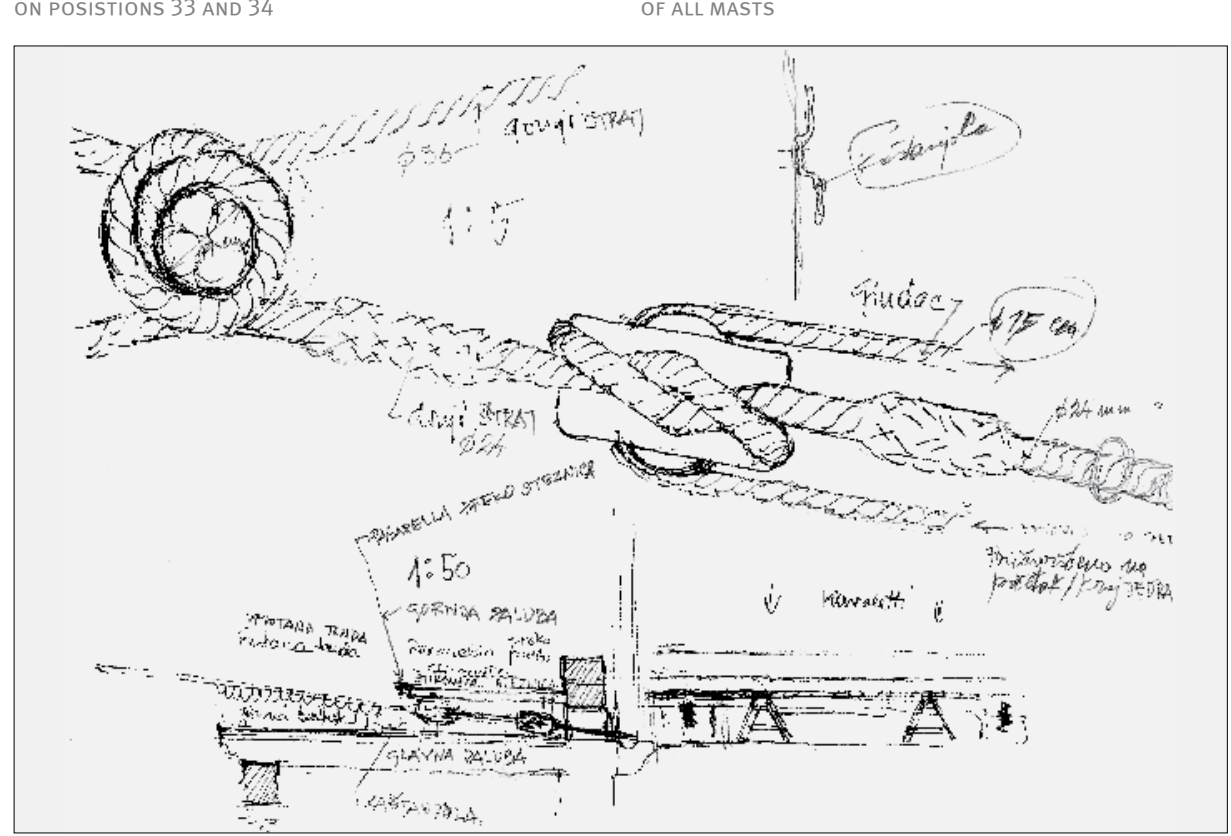

konstrukciju za sastavljanje, montažu, a potom i rukovanje velarijem (SI. 16., 19.-24.). U tom složenom poslu temeljna je drvena konstrukcija olakšala izradu i montažu summae cavee in ligneis na četvrtoj i petoj etaži te omogucila lakše prilagođavanje manjih nepravilnosti u tom završnom poslu na oblikovanje Amfiteatra. Manje prilagodbe izvedenih nepravilnosti lakše je bilo ispraviti na licu mjesta u drvu. Tu se posebice očituje nepravilan (nejednak) raspored zateznih dasaka (greda) u strukturi glavne palube kako bi se stabilizirala na potrebnim mjestima. U tom sustavu rasporeda sila i opterećenja vażnu su ulogu imale kamene bitve, čvrsto usidrene na užlijebljeni vijenac. Bilo je 68 izvornih kamenih bitvi $(1,10 \times 0,70 \mathrm{~m})$ iza drvenih jarbola $30 \times 30 \mathrm{~cm}$, usidrenih u užlijebljeni vijenac koji je zategnut $\mathrm{s}$ isto toliko nosivih donjih štraja, dok je 16 (4×4) manjih bitvi $(1,10 \times 0,50 \mathrm{~m})$ bilo zategnuto i usidreno iza manjih jarbola $20 \times 18 \mathrm{~cm}$. Ukupno je bilo usidreno na užlijebljeni vijenac $68+16=84$ bitve. Danas je očuvana na izvornome mjestu 51 bitva iza drvenih jarbola $30 \times 30 \mathrm{~cm}$ i tragovi sidrenja manjih jarbola $20 \times 18 \mathrm{~cm}$.

Kao što bitve duž obale luka služe privezu brodova, tako su i ove u sklopu velarija služile za njegov privez s osnovnom funkcijom nošenja jedra, kao i zatezanja donjega nosivog štraja (leta), za dobivanje pada velarija prema užlijebljenom vijencu i zatezanja gornjeg kraja štraja do gornjeg kraja jarbola. Od toga gornjeg kraja, od vrha jarbola, polazila su još dva zatezna konopa (sartie) koja su se vezivala na 4 tone teške kamene cipuse ugrađene $u$ okolni teren na nejednaku udaljenost, od 10,00 do 19,00 m, od vanjskoga kamenoga nosivog zida s kamenim arkadama do konačno zaravnatog terena u okolišu Amfiteatra. Ova dva zatezna konopa imala su zadacu da na taj način onemoguce lom jarbola kod djelovanja jačih vjetrova, kod rukovanja velarijem i kod upravljanja tijekom njegove uporabe (SI. 1., SI. 25.).

Sastavni su dijelovi velarija Amfiteatra konopi raznih profila nosive konstrukcije čvrsto usidrene u summu caveu s kojima se moglo lako rukovati; 3 palube potrebne raznim majstorima u stvaranju summu caveu i sastavljanju lančanice u određenom danom sustavu konopa; jarboli s ugrađenim ljestvicama koje omogucuju prilaze majstorima zbog raznih potrebnih popravaka; steznice (bigotte) na mjestima na kojima je potrebna veza konopa s nosivom konstrukcijom, primjerice veza sartie (pripone) s cipusom od 4 tone; veza donjega nosivog štraja (leta) od $24 \mathrm{~mm}$ na kamene bitve u razini glavne palube; veza i zatezanje gornjega zateznog štraja kojim se stvara pad konopa, potom i montiranog jedra ponad vanjskog ruba borilišta kako bi se do- 


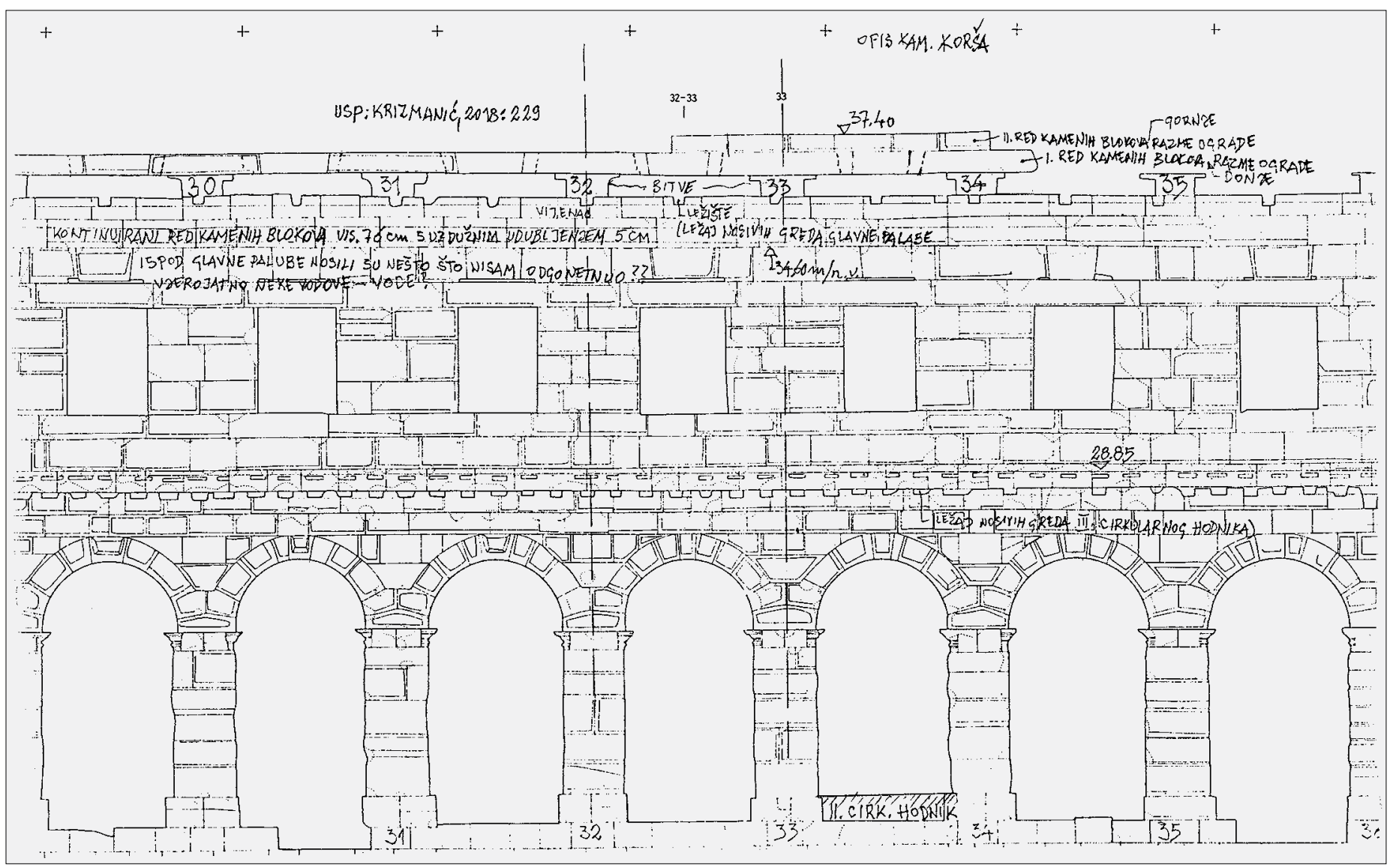

SL. 24. Pogled prema najVIŠEm diJelu Amfiteatra, NA POZICIJE BITVI 33 I 34, IZMEĐU STUBIŠNIH TORNJEVA NA $37,40 \mathrm{M} / \mathrm{N} . \mathrm{V}$.

Fig. 24 View OF THE HIGHEST PART OF THE AMPHITHEATRE, THE POSITIONS OF THE BOLLARDS 33 AND 34, BETWEEN THE STAIRCASE TOWERS ON $37.40 \mathrm{M}$ ABOVE SEA LEVEL
SL. 25. PRESJEK DUŻ KRAĆ OSI (18-19 / 54-55) S IDEALNO ZATEGNUTIM KONOPIMA STALNE POSTAVE KONSTRUKCIJE SLOŻENE LANĊANICE VELARIJA

FIG. 25 SECTION ALONG THE SHORTER AXIS (18-19/54-55) WITH THE IDEALLY TIGHTENED ROPES OF THE PERMANENTLY SET UP CONSTRUCTION OF THE COMPLEX VELARIA CATENARY

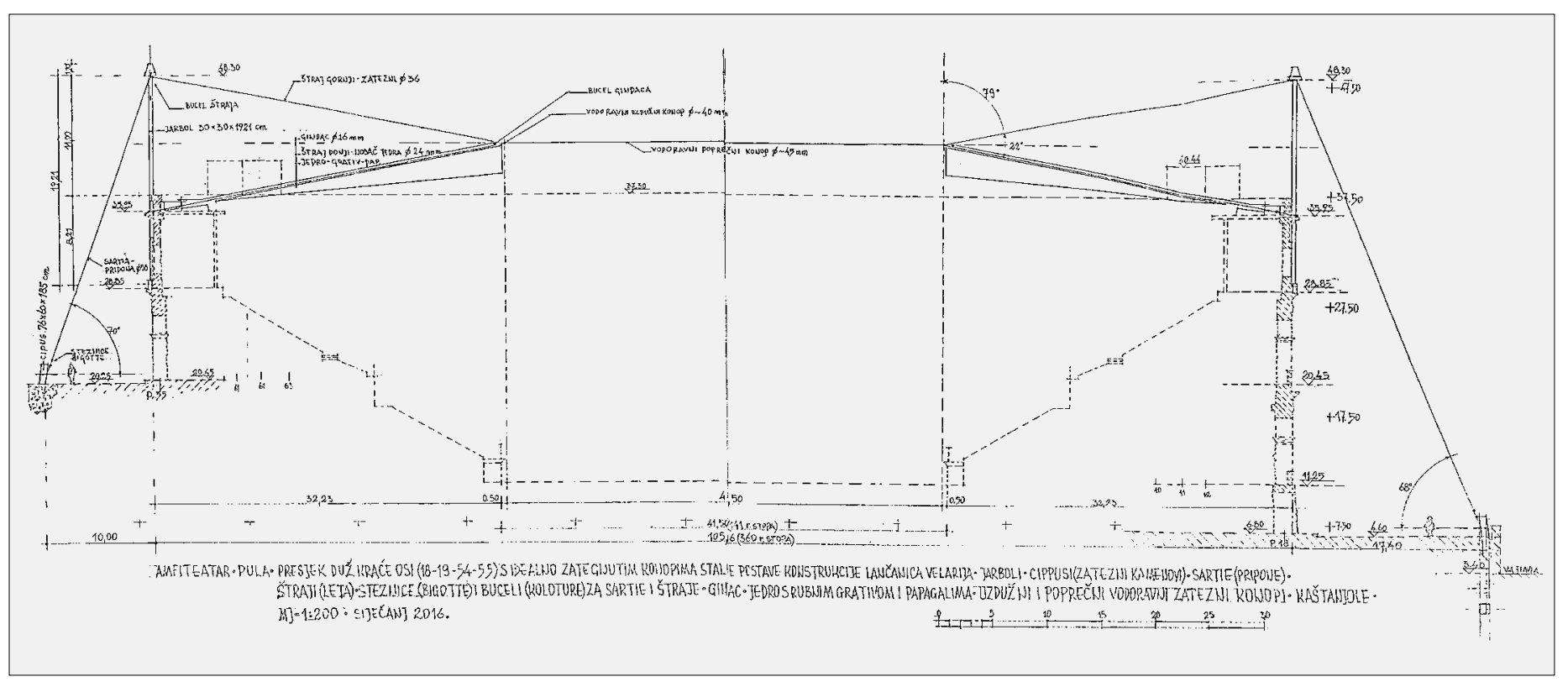




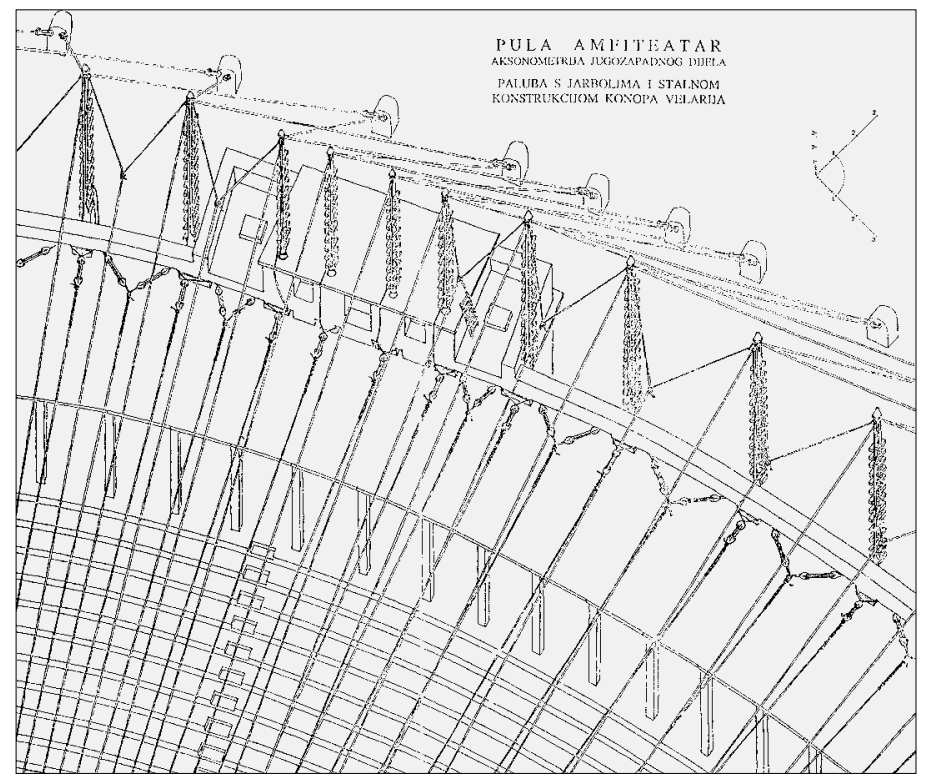

SL. 26. Prostorna skica glavne palube S Jarbolima I STALNOM KONSTRUKCIJOM KONOPA VELARIJA

FIG. 26 SPATIAL SKETCH OF THE MAIN DECK WITH MASTS AND A PERMANENTLY SET UP CONSTRUCTION OF THE VELARIA ROPES NA GLAVNOJ PALUBI

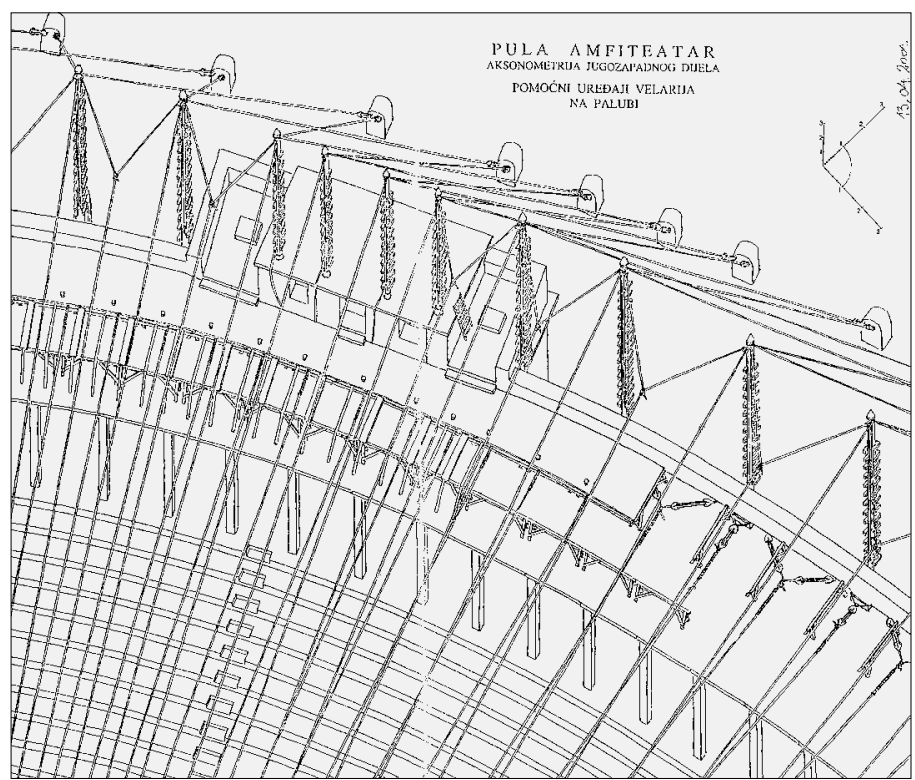

SL. 27. PROSTORNA SKICA POMOĆNIH UREDAJA VELARIJA

FIG. 27 SPATIAL SKETCH OF THE ACCESSORY EQUIPMENT OF THE VELARIA ON THE MAIN DECK
SL. 28. TLOCRT NA RAZINI GLAVNE PALUBE $(35,95$ M/N.v.), S 84 JARBOLA I STALNOM POSTAVOM KONSTRUKCIJE KONOPA VELARIJA (DOLJE)

FIG. 28 LAYOUT ON THE LEVEL OF THE MAIN DECK (35.95 M ABOVE SEA LEVEL) WITH 84 MASTS AND A PERMANENT CONSTRUCTION OF THE VELARIA ROPES (DOWN)

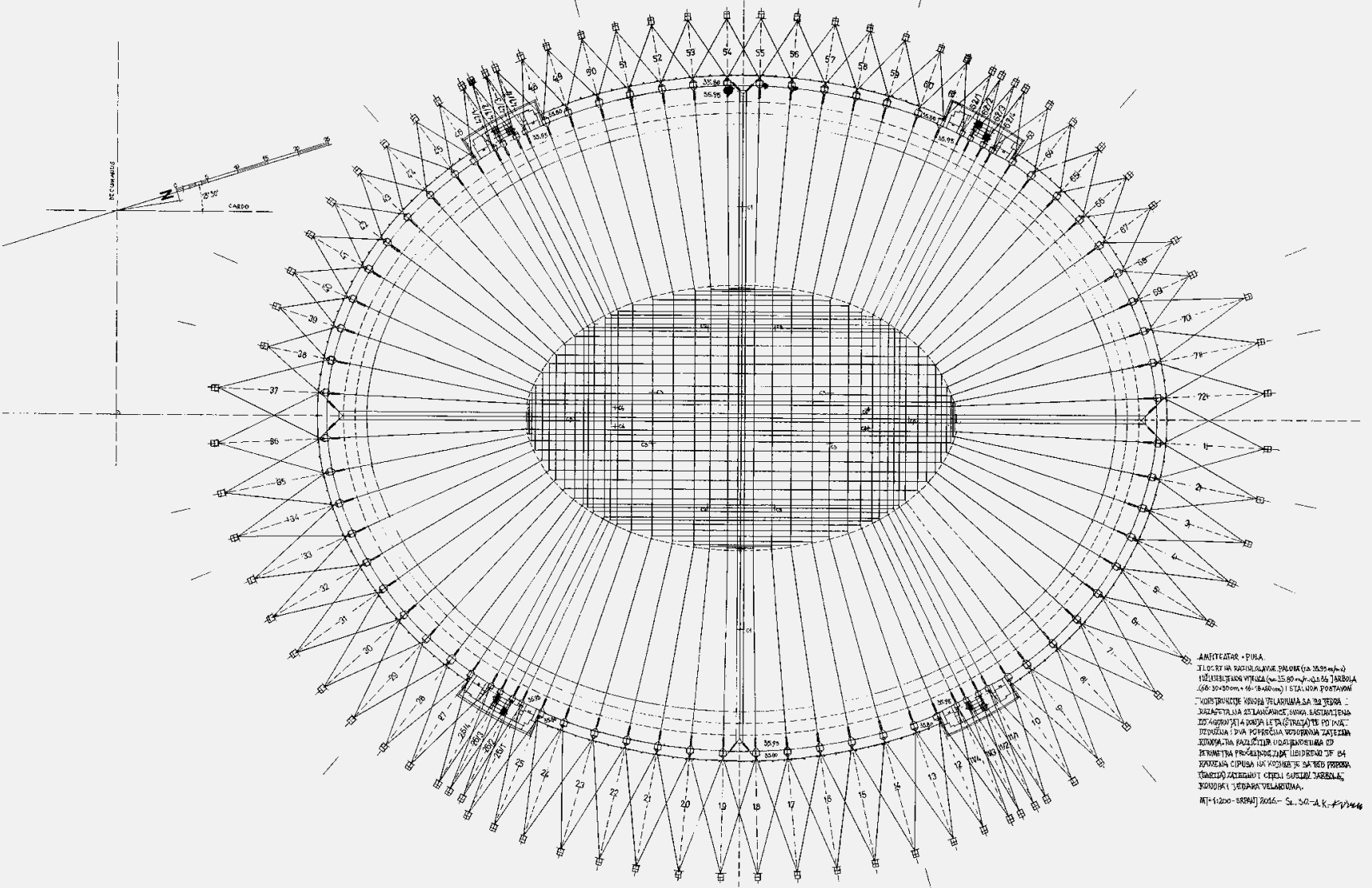




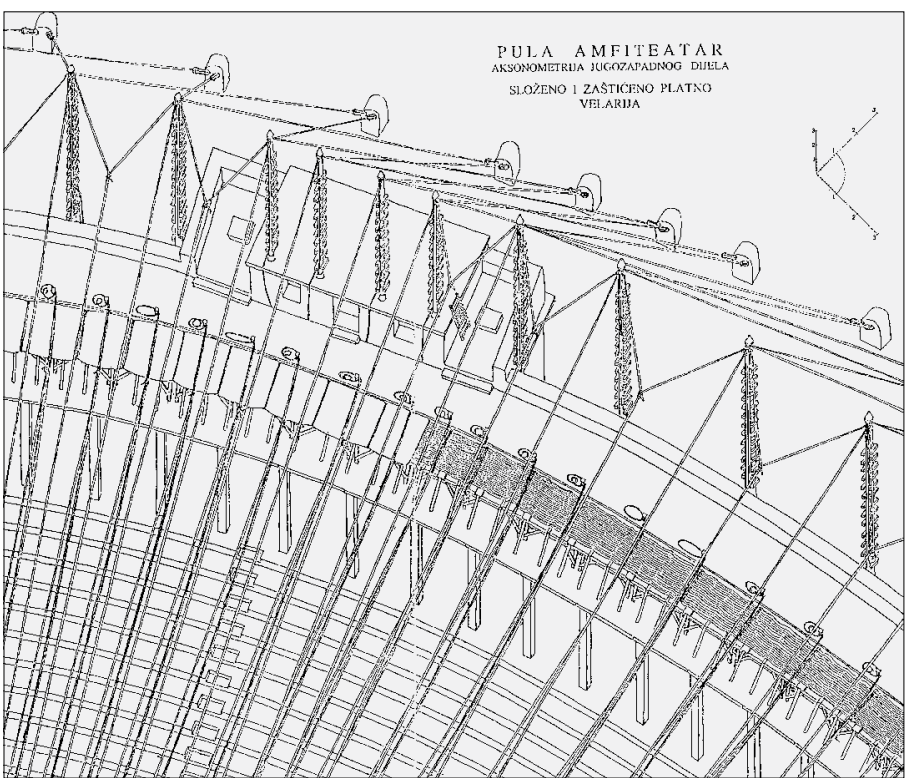

SL. 29. Prostorna SKICA SLOŻeNIH I ZAŠtićENIH JEDARA VELARIJA

Fig. 29 SPATIAL SKETCH OF THE COMPLEX AND PROTECTED VELARIA SAILS

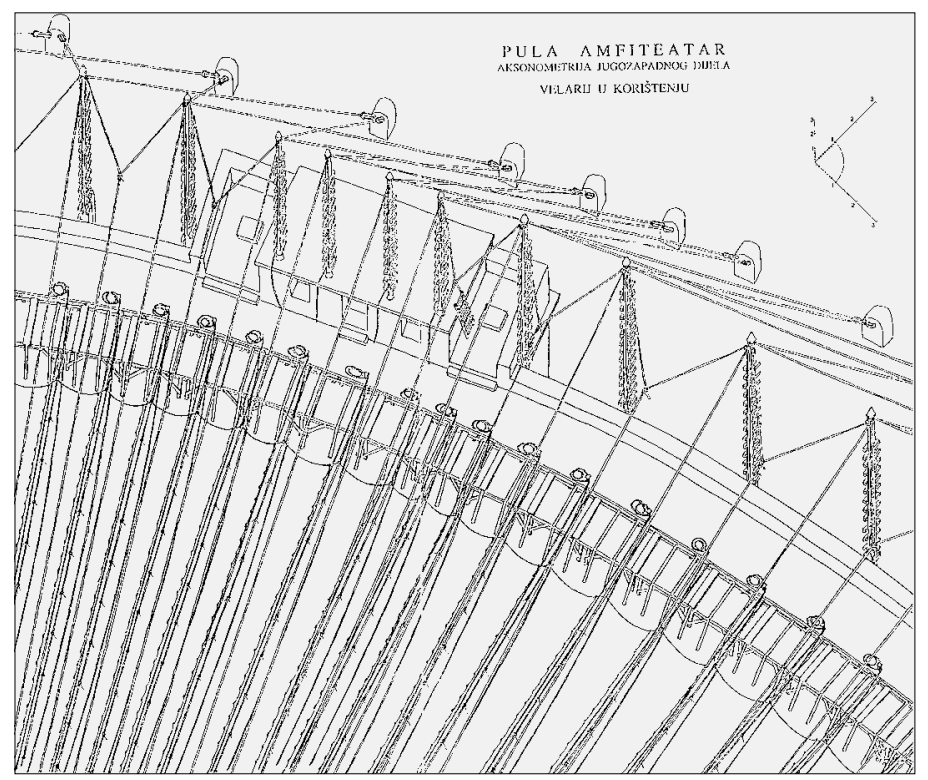

SL. 30. Prostorna SkICA Velarija U KoriŠtenJU FIG. 30 SPATIAL SKETCH OF THE VELARIA IN USE
SL. 31. TLOCRT NA RAZINI GORNIE PALUBE $(36,73 \mathrm{M} / \mathrm{N}$. V.), GORNJE KAMENE RAZME PALUBNOG BOKA $(37,30 \mathrm{~m} / \mathrm{N}$.v. $)$ I SKOŠENOG DIJELA GORNJE PALUBE (DOLJE)

FIG, 31 LAYOUT ON THE LEVEL OF THE UPPER DECK $(36.73 \mathrm{M}$ ABOVE SEA), THE UPPER STONE RASMA OF THE DECK FLANK (37.30 M ABOVE SEA LEVEL) AND THE BEVELED PART OF THE UPPER DECK (DOWN)

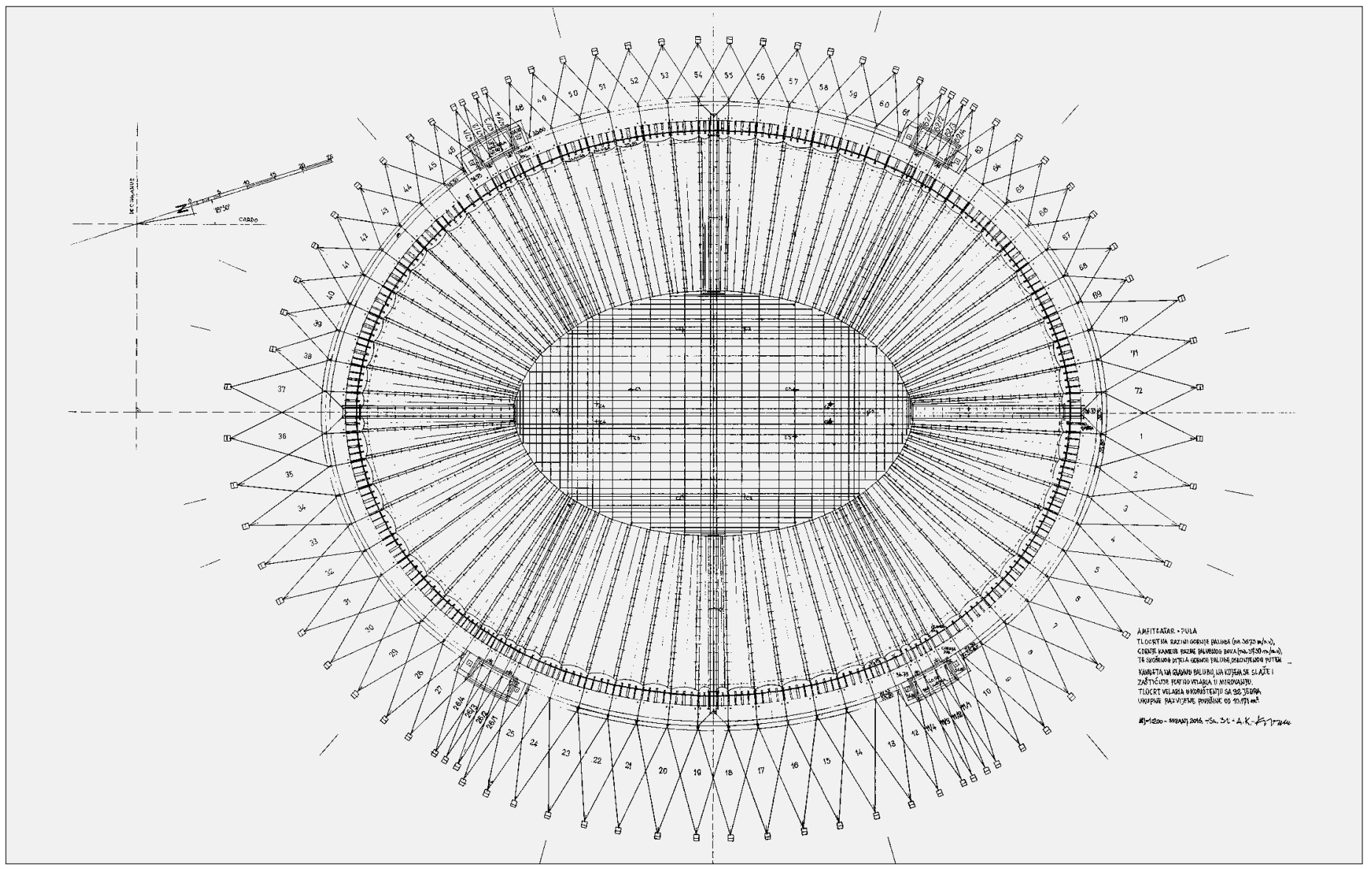


bio pad za prikupljanje kišnice prema glavnoj palubi, konačno sakupljenoj u širemu užlijebljenom vijencu, a preko rigalica izbačenoj izvan Amfiteatra. Uzdužni i poprečni vodoravni zateznici, konopi $\varnothing 45 \mathrm{~mm}$ u obliku različitih pravokutnika kojima se konačno oblikuju 23 nosive zatezne kompleksne lančanice radi zaštite od kiše i sunca s porubljenim krajem jedara (porub - grativ jedra) na kojem su pričvršceni željezni ili drveni klizači - papagali.

92 konopa - gindaca $\times 2=184, \varnothing 16 \mathrm{~mm} \mathrm{mi}$ nimalne dužine $60,00 \mathrm{~m}$, pričvršćeni na kraju/početku jedara za razvlačenje i pokrivanje gledališta, odnosno otkrivanje u ovisnosti o stanju jedara: zatvoreni ili otvoreni.

Sastavni dijelovi velarija, osim jedara, bili su konopi raznih profila sa svojim čvorovima vezama po užarskom zanatu. Nakon složenoga, katkad i mučnoga istraživanja, te izmišljanja raznih kombinacija čvorova ručne izvedbe sjetio sam se da je moj djed po materi bio još krajem 19. stoljeca vrhunski užar u austrijskom arsenalu, a vezujuci razne konope i čelične sajle za jarbole činio je čuda uporabom manjega broja raznog alata. Posebice pamtim jednu 'L' kuku učinjenu na ganać - plod iskustva i prakse $s$ kojom je pleo za nas mrežu konopa oko boca i drugi niz čvorova. To i drugo učio je u austrijskom arsenalu, u kojem se stoljecima prenosilo znanje, pa i onda kada se gradio samo jedan brod ili kada se čistilo samo dno brodova. Bilo je to sredinom 19. stoljeća (1846.), što označuje početak stvaranja novog arsenala i brodogradilišta. I užari su sudjelovali u prijenosu tradicije gradnje brodova. Od kada? Oduvijek! Od onoga dana kada su stari narodi počeli ploviti. Taj je stari zanat postojao oduvijek u Arsenalu, tijekom cijeloga predrimskog i rimskog doba do danas, kada je nasilno zatvoren pod imenom „Uljanik”. Imao je majstore i radnike te vezu sa starim zanatima. Kulturni ljudi čuvaju dvomilenijsku tradiciju.

U Puli su se gradili brodovi u doba podizanja Amfiteatra. Da su užari sudjelovali u gradnji, svjedoči mladi car August kojemu Marko Antonije predbacuje da je njegov pradjed (Augustov), slobodnjak iz Turijskog okruga (današnja Pulja), bio po zanimanju užar ${ }^{23}$ (SI. 26.-27., 29.-30.).

\section{ZAKLJUČAK}

\section{CONCLUSION}

„Svaki je njegov opis neprimjeren kada ga promatraš i diviš mu se. Jedinstveni spomenik takve vrste koji se uzdiže u očuvanom vanjskom zidu svojom ljepotom u svakom svom dijelu. Stoga nadmašuje glasovite amfiteatre, kao onaj u Veroni, Capui, Pompeju, Korintu pa i onaj isti Koloseum. S estetske strane pak ističe se među svima po čistoći, vitkosti i otmjenosti svojih formi." ${ }^{24}$

Velarij se definitivno počeo rješavati početkom 2014. godine, kada su konačno objašnjena ukrižana stubišta, bačvaste cisterne i tri palube u sklopu stubišnih tornjeva. Tada su se pojasnili položaj, dimenzije i namjena triju radnih površina paluba. Godine 1997. otkrio sam cetiri tanja jarbola velarija $(18 \times 20 \mathrm{~cm})$ koji su se uzdizali nad stubišnim tornjevima s manjim udaljenostima među njima (od 1,80 do 2,25 m). To je upucivalo na to da veci raspon među njima od 5,20 $\mathrm{m}$ treba $\mathrm{u}$ izvedbi velarija raspoloviti na $2,60 \mathrm{~m}$. Međutim, nakon grafičke provjere to je napušteno ${ }^{25}$ kao previše gusto i složeno rješenje, osobito na početku, a najviše na krajevima jedara iznad ruba borilišta - arene. Te iste godine u sva čtiri tornja namještena je vrhunska skela koja je omogućila uvid i grafičko bilježenje u svaki dio unutarnjih stijena četiriju stubišnih tornjeva - ključ za otkrivanje novih znanja u rješavanju ukrižanih stubišta, velarija i tornjeva u cjelini, u kontekstu dotad nepoznate, ali često spominjane etaže summae caveae in ligneis. Isto tako, otkriveno je rješenje plitkog ležaja s tri kanalica i zateznom daskom te činjenica da je stubišni toranj između bačvastih cisterni bio viši za oko 3,14 m. Rimska Pula u spomenutom je austrijskom arsenalu, $u$ tom njegovu prvotnom prostoru, danas na Trgu Dante Alighieri, uvijek gradila i popravljala brodove, vjerojatno i prije rimskog razdoblja, jer znamo da su stari Histri bili dobri moreplovci. Stvaralo se i prenosilo znanje u gradnji brodova preko svih onih zanata koji su uvijek sudjelovali u njihovu stvaranju do 19. stoljeća s manje-više istom ili sličnom tehnologijom. ${ }^{26}$

Poznato je da su se gladijatorske i druge borbe reklamirale. Natpis sačuvan na jednom

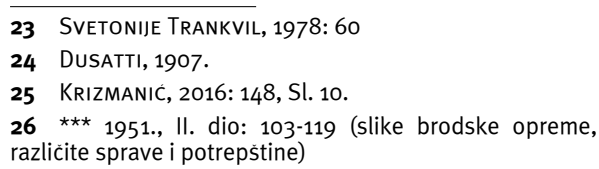


pročelju zgrade ulice „Dell'abbondanza” u Pompeju to dokazuje. Na toj osobitoj staroj reklami piše sve što ce se održavati u Amfiteatru, od svečanog otvaranja do opisa svih događaja. Između ostaloga napisano je da ce gledatelji moći koristiti i biti u sjeni, zaštičeni hladovinom velarija (vela erunt). Posebno je naglašeno da ce velarij biti prostrt ponad gledališta da ih zaštiti od nebeskih nepogoda ili prejakog sunca. Isticanjem natpisa vela erunt podrazumijevalo se što se pod time sve smatralo.

Prema tome, kako bi se moglo organizirati učinkovito stvaranje velarija, moralo se najprije završiti cjelovitu kamenu i drvenu konstrukciju na četvrtoj i petoj etaži u stubišnim tornjevima, tzv. summa cavea in ligneis istodobno s dovršenjem četiriju stubišnih tornjeva s deset drvenih ukrižanih stubišta sa završenom drvenom palubom Kaštela na koti 40,00 m/n.v.; s gornjom palubom (palubom Kavaleta) na koti 38,73 m/n.v.; s glavnom palubom na koti $35,95 \mathrm{~m} / \mathrm{n}$.v. i s užlijebljenim vijencem na koti $35,80 \mathrm{~m} / \mathrm{n} . v$. - na kojima se stvaralo, sklapalo i upravljalo velarijem.

Summa cavea in ligneis u pretežitom je dijelu bila iz drva koji je pratio nosivu kamenu konstrukciju vanjskoga cirkularnog zida, od III. cirkularnog hodnika (na $28,85 \mathrm{~m} / \mathrm{n} . v$.) do kote $37,35 \mathrm{~m} / \mathrm{n} . v$. između stubišnih tornjeva i do kote 40,00 m/n.v. (paluba Kaštela) u pojasu četiri stubišna tornja između dviju cisterna na svakom tornju. Summa cavea započinje s drvenom konstrukcijom III. cirkularnog hodnika i nastavlja ponad njega s drvenim stupovima $30 \times 30 \mathrm{~cm}$ koji nose drvenu glavnu palubu na rasponu osovine kamenih pilastara III. i IV. reda do 6,50 m širine. Velarij je bio toliko važan da se prije početka igara moralo napisati na plakatu da ce postojati mogućnost korištenja velarija isticanjem parole VELA ERUNT.

U obrambenom zidu, ne u ogradi, novoga austrijskog arsenala čuvaju se i blokovi kamena Amfiteatra. Nedavno je neka politička glava samodopadno izjavila da brodogradilište u Puli ne može egzistirati na samo $200 \mathrm{~m}$ od Amfiteatra. Ova nakaradna razmišljanja novijega su postanja kako bi se moglo dobiti licencu za rušenje svega oko Amfiteatra i tako dobivene praznine ispuniti nasumičnom sadnjom borova i zgaženom travom. Zar su tako stvoreni ambijenti sa stablima pulsko graditeljsko naslijeđe? Zar se tako stiti povijesna jezgra i povijest grada Pule!? Rušenjem oko 200 zgrada poslije Drugoga svjetskog rata a da se ne ostavi trag o njihovu postojanju? Još je 1974. godine na jednom simpoziju povjesničara umjetnosti u Puli u novom Hotelu Brioni prof. Milan Prelog bio slikovito rekao da pulskoj jezgri tako nedostaje trbuh koji hrani grad i da se tu prazninu, stvorenu i angloameričkim bombama, mora rekonstruirati - ispuniti, naravno zgradama, a ne żgembavim borovima.

Na kraju izdvojit cemo i sažeti popis glavnih dijelova i elemenata koji čine velarij. Svaka od 23 složene lančanice bila je razapeta na 4 jarbola u odnosu na 4 pilastra pomoću 8 štraja - leta: 4 donja štraja koji nose jedra i 4 gornja zatezna štraja putem bucela vezani su za vrh jarbola. Ukupno 92 donja leta + 92 gornja leta $=184$ leta; 68 jarbola $30 \times 30 \mathrm{~cm}$ i 16 jarbola $18 \times 20 \mathrm{~cm}$, a to ukupno čini 84 jarbola; $168(84 \times 2)$ sartija - pripona; 84 cipusa. Svaki pojedini krak cetverokrake lancanice smješten je u svojoj zasebnoj jednoj četvrtini, u svome posebnom kvadrantu osnovne konstrukcijske mreže konopa velarija s jednim stubišnim tornjem, na ciijoj je istaknutoj ravnoj palubi Kaštela (na 40,00 m/n.v.) zapovjedno mjesto upravljanja $1 / 4$ velarija. Prema tome, svaka je lancanica velarija bila odredena s 4 gornja i 4 donja straja - leta, te s dva poprecna zatezna (paralelna s kracom osi) $i$ dva uzdużna zatezna (paralelna s dużom osi) konopa koji su povezivali vodoravno svih 8 straja u jedinstven statički sustav. Kako bi se pomoglo da se stabiliziraju i uravnoteže 84 jarbola i tako spriječilo njihov lom zbog djelovanja lančanica s rastegnutim jedrima, cesto pod utjecajem vjetra i drugih sila potaknutih upravljanjem velarija, svaki je jarbol bio opremljen dvjema sartie - priponama (zateznim konopima) koje su ukoso išle od njegova vrha do odgovarajucega kamenog cipusa, usidrenog u teren na 10 do 18 m udaljenog od vanjskoga zidnog plašta (SI. 28., 31.). Takvih je 5 cipusa očuvano u okolišu Koloseuma u Rimu na udaljenosti 17,50 m od vanjskog plašta.

Naš Amfiteatar, koji ističe svoja jedra na $11.466,00 \mathrm{~m}^{2}$, predstavlja u simbiozi s kamenim pročeljem bijele boje izuzetnu sliku golemoga jedrenjaka. 


\section{LITERATURA}

\section{BIBLIOGRAPHY}

1. Beste, H.-J. (2001.), I sotterranei del Colosseo (Podzemlje Colossea, uređaji i postrojenja, promjene i funkcioniranje), u: Sangue e Arene (priredio: LA ReginA, A.): 277-278, Milano

2. CARLI, G. (1793.), Delle antichità italiche, Parte Seconda, Libro terzo, Velario ossia tendone: 219-226., TAV. XV: 223 (nacrt tlocrta i presjeka velarija): 207-237, 233-237, zaključak, Milano

3. Coarelli, F.; Franzoni, L. (1972.), Arena di Verona, venti secoli di storia (Arena u Veroni, dvadeset stoljeca povijesti), Plan velarija autora Carla Fontane: 43, Verona

4. Durm, J. (1905.), Die Baukunft der Römer, Stuttgart

5. Dusattı, U. (1907.), Catalogo delle collezioni antiche del Museo di Pola, Katalog antičkih Kolekcija Civilnog muzeja Pule: 6-7, Pula

6. Graefe, R. (1979.), Vela erunt, English Summary: 221, Mainz am Rhein

7. Izenour, G.C. (1992.), Roofed Theaters of Classical Antiquity, vol. XXXI, Yale University Press, New Haven and London

8. Krizmanić, A. (1988.), Komunalna palaca Pula. Razvitak gradskog sredista kroz dvadeset jedno stoljece, Pula

9. Krizmanic, A. (2016.), Amfiteatar u Puli, istrażivanja o izvornom izgledu iz sredine 1. st. pr. Kr., „Prostor”, 24 (2/52/): 132-155, Zagreb, https://doi.org/10.31522/p.24.2(52).1

10. LUCIANI, R. (2000.), Il Colosseo, Milano

11. MAffel, S. (1728.), Degli Anfiteatri e singolarmente del Veronese, libri due: 290-297, Velario di Carlo Fontana, architetto 1714: 314-342 (TAV. XII.), Verona

12. Marasovic, J.; Krizmanic, A.; Marasovic, D. (1988.), Amfiteatar u urbanoj strukturi Pule, „Pogledi”, 18 (3-4): 875-906, Split

13. Pevsner, N.; Fleming, J.; Honodur, H. (1992.), Dizionario di architettura, 220, Carlo Fontana, Torino

14. REA, R. (2001.), L'Amfiteatro di Roma: note strutturali e di funzionamento (Amfiteatar u Rimu: napomene ustroja i funkcioniranja), $u$ : Sangue e Arena [priredio: LA REgINA A.]: 69-77, Milano

15. Stancovich, P. (1822.), Dello Anfiteatro di Pola, Venezia

16. Svetonije Trankvil, G. (1978.), Dvanaest rimskih careva, car August: 59-60, Rijeka

17. $* \star \star ~(1912 . / ? /)$, Il Melzi Scientifico, 373: Fontana, Giovanni, Domenico e Carlo - tri znamenita ticinska arhitekta koji su uljepšali Rim novim građevinama u 16.-18. stoljecu. Milano (?)

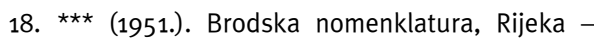
Split

19. *** (1973.), Enciclopedia Dell'Arte Garzanti

\section{IZVORI}

\section{SOURCES}

IZVORI ILUSTRACIJA

ILLUSTRATION SOURCES

SL. 1.-2., 6.-9.

11.-12., 14.,

22., 24.-25.,

28., 31.

A. Krizmanić (razmišljanja sa skicama/slikama mogucih i nemogucih rješenja sustava i konstrukcije čvorova našeg velarija)

SL. 3.

SL. 4.

R. Sbisà, u: CARLI, 1793.

STANCOVICH, 1822.

SL. 5.

C. Fontana, u: MAFFEI, 1728.

SL. 10., 15.,

17.-18., 23.,

26.-27., 29.-30

J. Marasović

St. 13., 16., 19.-21. A. Krizmanic i J. Marasovic 


\section{SAŽETAK}

SUMMARY

\section{Amphitheatre in Pula}

VELARIUM

The research presented in this paper is part of a more extensive research on possibly diverse velarium systems. At the beginning of this brief description of the velaria, it is necessary to list the main parts and elements that make up a velarium system. Each of the 23 complex catenaries was stretched over 4 masts connected to 4 pilasters by means of 8 backstays: 4 lower backstays that carry the sails and 4 upper tensioning backstays by means of tackles tied up to the top of the mast in order to elevate their middle parts and create a bell above the auditorium with a slope towards the main deck so that rainwater could be directed to the grooved cornice and waterspouts. A total of 92 lower backstays +92 upper backstays $=184$ backstays: 68 masts $30 \times 30 \mathrm{~cm}$ and 16 masts $18 \times 20 \mathrm{~cm}$ making up a total of 84 masts, $84 \times 2=168$ shrouds and 84 cippi.

Each individual arm of the four-legged catenary is located in its own separate quarter in its special quadrant of the basic construction network of the velarium ropes with one staircase tower on which is placed the prominent flat deck (at $40.00 \mathrm{~m}$ above sea level) with the command post of the velarium. Therefore, each catenary of the velarium was determined by 4 lower and 4 upper backstays as well as with 2 longitudinal tensioning (parallel with the longer axis) and 2 transversal tensioning (parallel with the shorter axis) ropes that connected horizontally all 8 backstays into a unique static system. In order to help stabilize 84 masts and prevent their breakage due to the activity of the catenary with stretched sails, often under the impact of the wind or other pressure caused by operating the velarium, each mast was equipped with two shrouds (tension ropes) that stretched from its top to the stone four-ton cippus anchored in the terrain at 10 to $18 \mathrm{~m}$ distance from the outer wall. Five such cippi have been preserved around the Colosseum in Rome at a distance of $17.50 \mathrm{~m}$ from the front wall. Many more cippi have been preserved in the amphitheaters of Santa Maria Capua and Pozzuoli while in Pula probably only one was discovered in 1933, yet unrecorded.

\section{BIOGRAFIJA}

\section{BIOGRAPHY}

Dr.sc. Attilio Krizmanić, dipl.ing.arh., rođen je 1935. u Puli. Diplomirao je 1963., magistrirao 1984. i doktorirao 1998. godine na Arhitektonskom fakultetu Sveučilišta u Zagrebu. Do 1970. projektirao je nastambe i brodske interijere $\mathrm{u}$ Brodogradilištu „Uljanik”. Uveo je praksu pripreme planova prostornog uređenja u procesu izgradnje i obnove grada. Voditelj je pripreme svih urbanističkih planova od 1971. do 1990. Objavio je 5 monografija o graditeljskom naslijeđu Pule. Tijekom 2014.-2017. dovršio je oko 150 grafičkih prikaza detaljne studije o izvornom stanju Amfiteatra u Puli sredinom 1. stoljeca pr.Kr.
The discovery from 1997 of four slender velarium masts rising above the staircase towers with smaller spans between them indicated that a larger span of $5.20 \mathrm{~m}$ should be divided into two parts. However, this was abandoned after a graphic check-up showed that it was too dense and too complex. Dyggve [1933: 124] states “... that the few persons needed to service the velum could move freely on the roof (...) covered with solid Roman tiles...”. At that time, Dyggve was not dealing with the velarium, so he could not possibly know that during its operation there were not just few people engaged in it but at least 400 disciplined sailors while for the first assembly and disassembly of the velaria around 1000 experienced sailors and various craftsmen were working on it. During the first assembly and management of a number of elements of a complex velarium catenary, it is impossible to imagine that this can be done on a 180 to 200 sloping roof surface covered with Roman tiles, while on a 10 to 20 sloping wooden deck it can certainly be done effectively. Decks, not the roof, are not just places to walk on, but also places to work, create, assemble and spread out the velarium units.

While studying the possibility that rope makers might have actively worked and cooperated in the creation of the velaria, I learned that the greatgrandfather of the emperor Augustus was a rope maker. Where did a large number of sailors (nautae) and military sailors (classiarii) in the first preparation, assembly and initial management of the velarium in Pula come from? During the reign of the emperor Augustus, a real permanent navy appeared with permanent stations divided into two squadrons: a Mediterranean squadron based in Punta Miseno, near Naples, classis Misenensis; and an Adriatic one based in Ravenna, classis Ravennas. When more sailors and other craftsmen were needed, they came from Ravenna as it was close to Pula. However, it should not be forgotten that Pula with its port and arsenal was an important naval station with a large number of sailors and masters of all crafts, who were needed for the construction of the Amphitheater so it was easy to organize a unit of sailors - vexillatio classiarii. Thus, our Amphitheater in Pula's bay - port can be related to the construction of ships in its Roman arsenal, located in the area of today's Dante Alighieri Square where ships were always built and masters of various crafts learned their skills. All of them were actually needed for the construction of the velaria. Probably the ingenious ideas such as our summa cavea in ligneis with the velarium, were born in the field of shipbuilding engineering much earlier than in the period of thriving Roman engineering.

In the design of the Amphitheater the undisputed ruler was in all things the architectus while in the execution of the Amphitheater the praefectus faber ruled with his teams of masters. In the construction of the fourth and fifth semi-storey and the deck in summa cavea in ligneis with the construction of about 60 entrance gates in the basement and in the first and second circular corridor, the carpenters (axe masters) came to the fore. In the complex performance of the velaria, sailors, rope makers and tailors of sails played an important role, probably with their orally transmitted hidden secrets about its effective work.

Vitruvius did not even mention the velaria, Gianrinaldo Carli (1788) and Pietro Stancovich (1822) set up a system that served as the protection against sun and rain, but their masts used to collapse due to the absence of shrouds. Their system as a whole does not follow a polycentric curve. In 1915, Anton Gnirs completely denied the possibility of the existence of the velaria while the masts that he could not deny, only served him to make up ridiculous and unnecessary constructions. In his extensive work on velaria in 1979, R. Graefe proposed some strange constructions that he could not integrate into systems, so he concluded that the velaria served only as protection from the sun and not from rain. However, his proposal clearly shows that he did not understand any of the unique remains of the grooved cornices and rasma at positions 32 and 33 preserved to this day in their original condition in our Amphitheater.
AtTIlio Krizmanić, Ph.D., Dipl.Eng.Arch., born in 1935 in Pula. He graduated in 1963, received his M.Sc. degree in 1984 and his Ph.D. in 1998 from the Faculty of Architecture in Zagreb. Until 1970 he designed ship interiors in the shipyard "Uljanik". He introduced the practice of preparing physical plans in the process of urban development and revitalization. He was in charge of all urban planning projects between 1971 and 1990. He published 5 monographs on the built heritage of Pula. Between 2014 and 2017 he completed around 150 graphic studies on the original condition of Pula Amphitheatre in the mid-1 ${ }^{\text {st }}$ century BC. 
